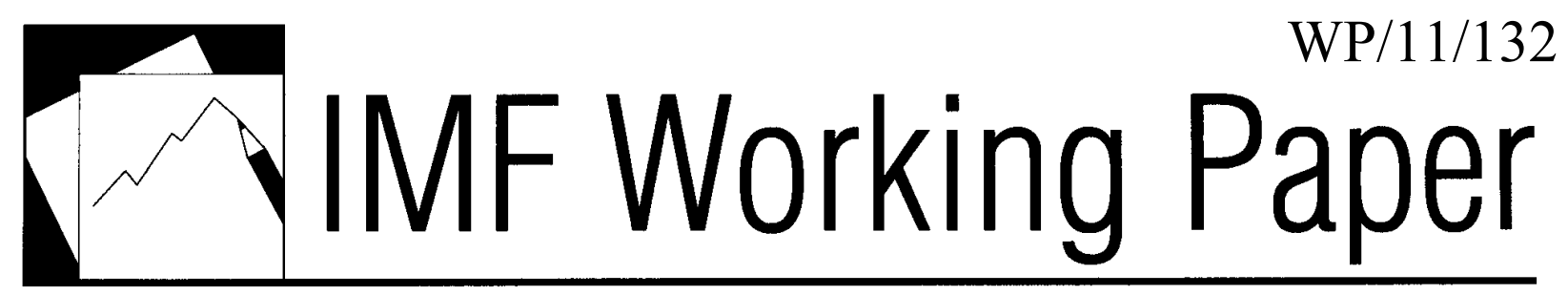

\title{
The Development of Local Debt Markets in Asia
}

\author{
Mangal Goswami and Sunil Sharma
}




\title{
IMF Working Paper
}

IMF-Singapore Regional Training Institute

\section{The Development of Local Debt Markets in Asia \\ Prepared by Mangal Goswami and Sunil Sharma ${ }^{1}$}

June 2011

\begin{abstract}
The paper makes an assessment of the progress made in developing local debt markets in emerging Asia. Market development has been limited by hurdles confronting borrowers and lenders, current and potential liquidity providers, and insufficient support from government policies and regulations. Besides fostering a credit culture to deepen local debt markets, the issue of critical size can be addressed through an integrated regional market for local currency bonds that provides greater scale, efficiency, and access. With rapid economic growth in Asia, a key challenge is to generate financial assets that can provide the underlying collateral for expanding fixed-income markets, and hence domestic and regional investment opportunities.
\end{abstract}

JEL Classification Numbers: E44; F36; G18; H63; O16.

Keywords: Capital markets; local currency debt markets; investor base; liquidity; bank lending; derivative markets; regulatory framework.

Author's E-Mail Address: mgoswami@,imf.org, ssharma@,imf.org.

\section{This Working Paper should not be reported as representing the views of the IMF.} The views expressed in this Working Paper are those of the author(s) and do not necessarily represent those of the IMF or IMF policy. Working Papers describe research in progress by the author(s) and are published to elicit comments and to further debate.

\footnotetext{
${ }^{1}$ Sunil Sharma and Mangal Goswami are Director and Deputy-Director of the IMF-Singapore Regional Training Institute, respectively. For helpful discussions and comments, the authors would like to thank colleagues at the IMF's Asia-Pacific Department, staff of the Monetary Authority of Singapore, and participants at the ADB-Bank Negara seminar on Macroeconomic and Financial Stability in Asian Emerging Markets held in Kuala Lumpur on August 4, 2010. The usual disclaimer applies.
} 
Contents

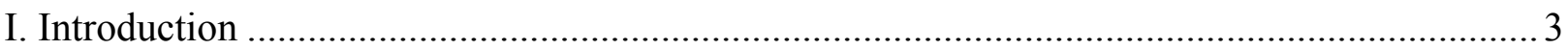

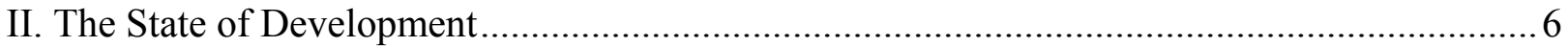

A. Borrowers and Lenders in the Local Markets ............................................................... 6

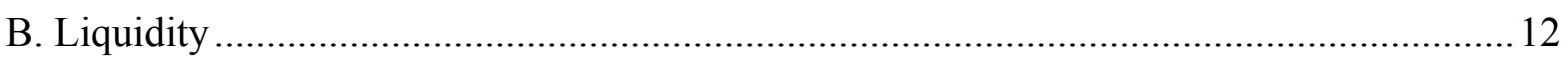

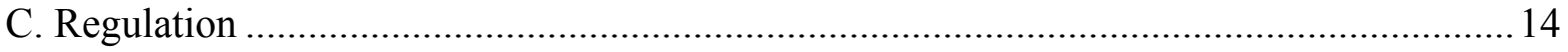

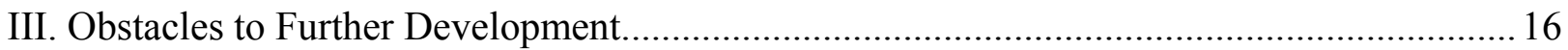

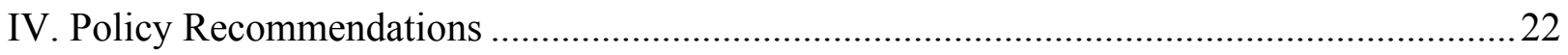

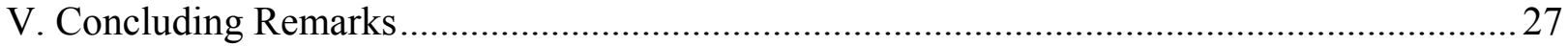

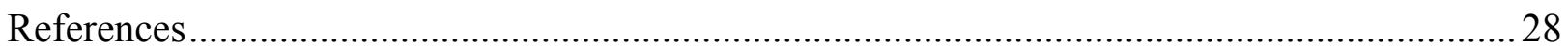

Figures

Figure 1. Emerging Bond Markets: Currency Denomination.................................................

Figure 2. Capital Inflows to Selected Asian Markets ......................................................... 4

Figure 3. Equity and Bond Market Indices ................................................................... 5

Figure 4. Capitalization of Bond Markets in Emerging and Developing Asia ..........................5

Figure 5. Selected Asian Bond Markets ......................................................................... 7

Figure 6(a). Institutional Assets in Selected Asian Markets................................................... 9

Figure 6(b). Hong Kong SAR and Singapore: Total Assets of.......................................... 10

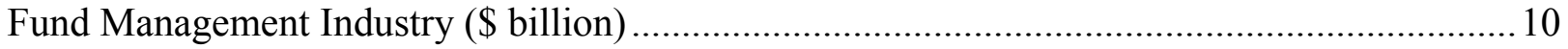

Figure 7. Foreign Holdings of Local Currency Government Bonds ...................................... 10

Figure 8. Investor Profile for Domestic Government Bonds .................................................. 17

Figure 9. Domestic Bond Markets and Impediments to Contracting ..................................... 19

Figure 10. Over-the-Counter Derivatives Markets .......................................................... 21

Tables

Table 1. Domestic Bond Market Liquidity Indicators ....................................................... 13

Table 2. Accessibility, Taxation, Funding and Hedging .............................................. 18

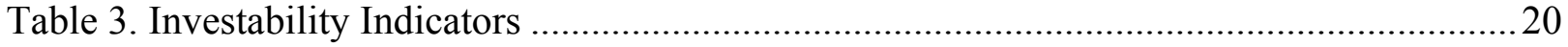




\section{INTRODUCTION}

Since the regional financial crisis of 1997-1998, Asian emerging markets have focused considerable attention on developing domestic debt markets to reduce foreign exchange mismatches in their financial systems and to decrease the concentration of credit and maturity risks in banks (Committee on the Global Financial System [CGFS] 2007b and Turner 2009). Besides building large foreign exchange reserve buffers, much of the effort has gone into local currency bonds since they constitute a significant share of emerging bond markets, especially in Asia (Figure 1). Liquid and deep domestic debt markets are seen as vehicles for diversifying the funding of governments, households, and corporations; attracting the financing required for huge infrastructure needs; broadening the range of assets available for local institutional and retail investors; and providing an additional channel for financial intermediation should the banks come under stress (Gyntelberg, Ma, and Remolona (2006); Gyntelberg (2007); Jiang, Tang, and Law (2002)). In addition, as financial development has proceeded, Asian policy-makers have come to appreciate the synergies and interrelationships between (i) creating capital and derivative markets, and (ii) modernizing bank and nonbank financial intermediaries.

Figure 1. Emerging Bond Markets: Currency Denomination

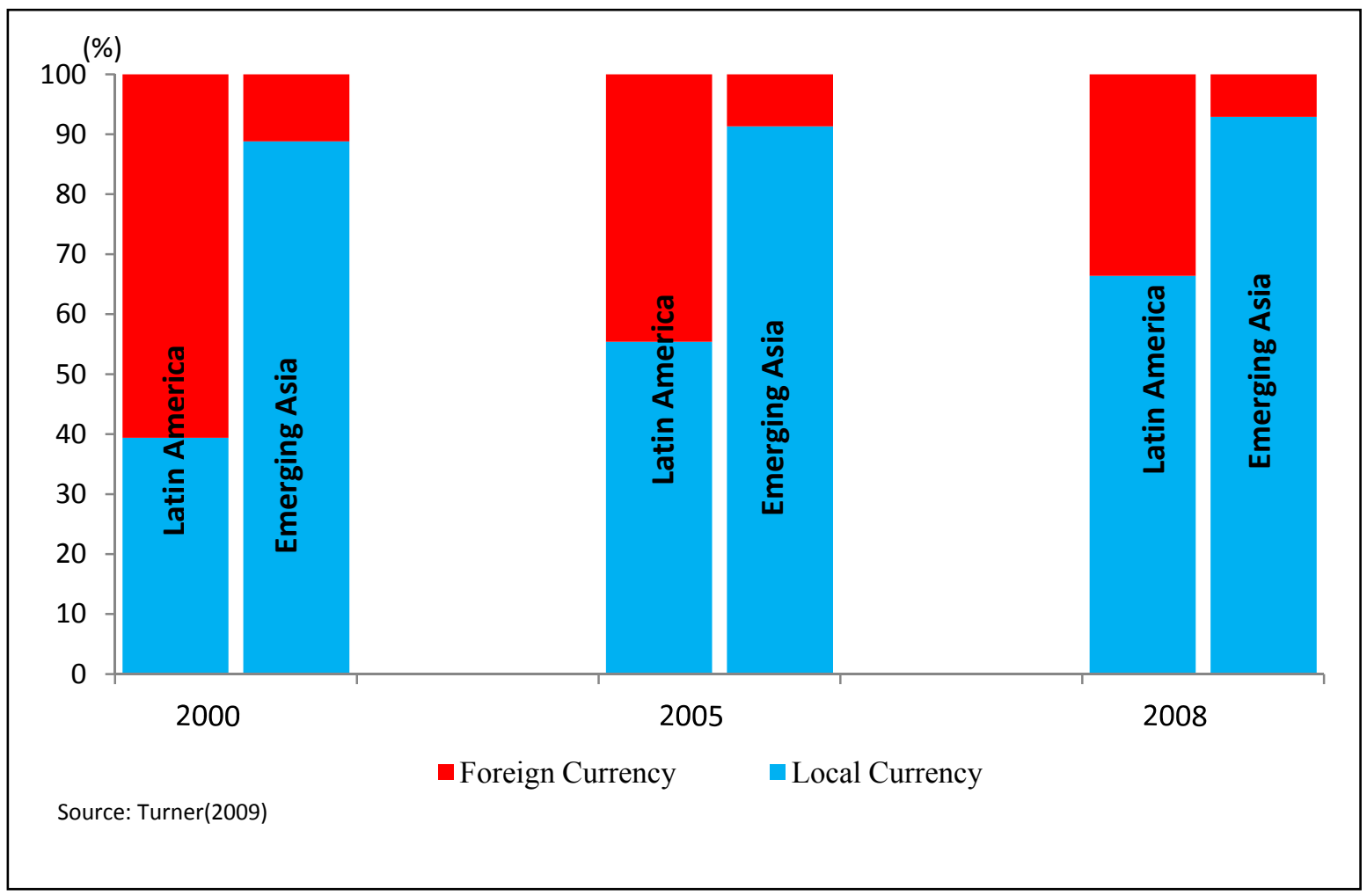

Asian capital markets that had grown faster than many of the mature markets since the turn of the century saw a sizeable retrenchment during the global financial crisis as capital inflows fell precipitously (Figure 2). Many of the emerging Asian asset markets experienced intense pressures as foreign investors withdrew (Figure 3). In particular, local debt markets - the 
focus of this study - saw high volatility and substantially lower liquidity at the height of the crisis in the last quarter of 2008. Tight global conditions, fragile investor confidence, and the sharp drop in sterilization by central banks and monetary authorities in the face of capital outflows, led to a drop in domestic bond issuance in 2008. Subsequently, fiscal stimuli and renewed capital inflows to the region resulted in a recovery of Asian domestic bond markets in 2009 .

\section{Figure 2. Capital Inflows to Selected Asian Markets}

(\$ billion)

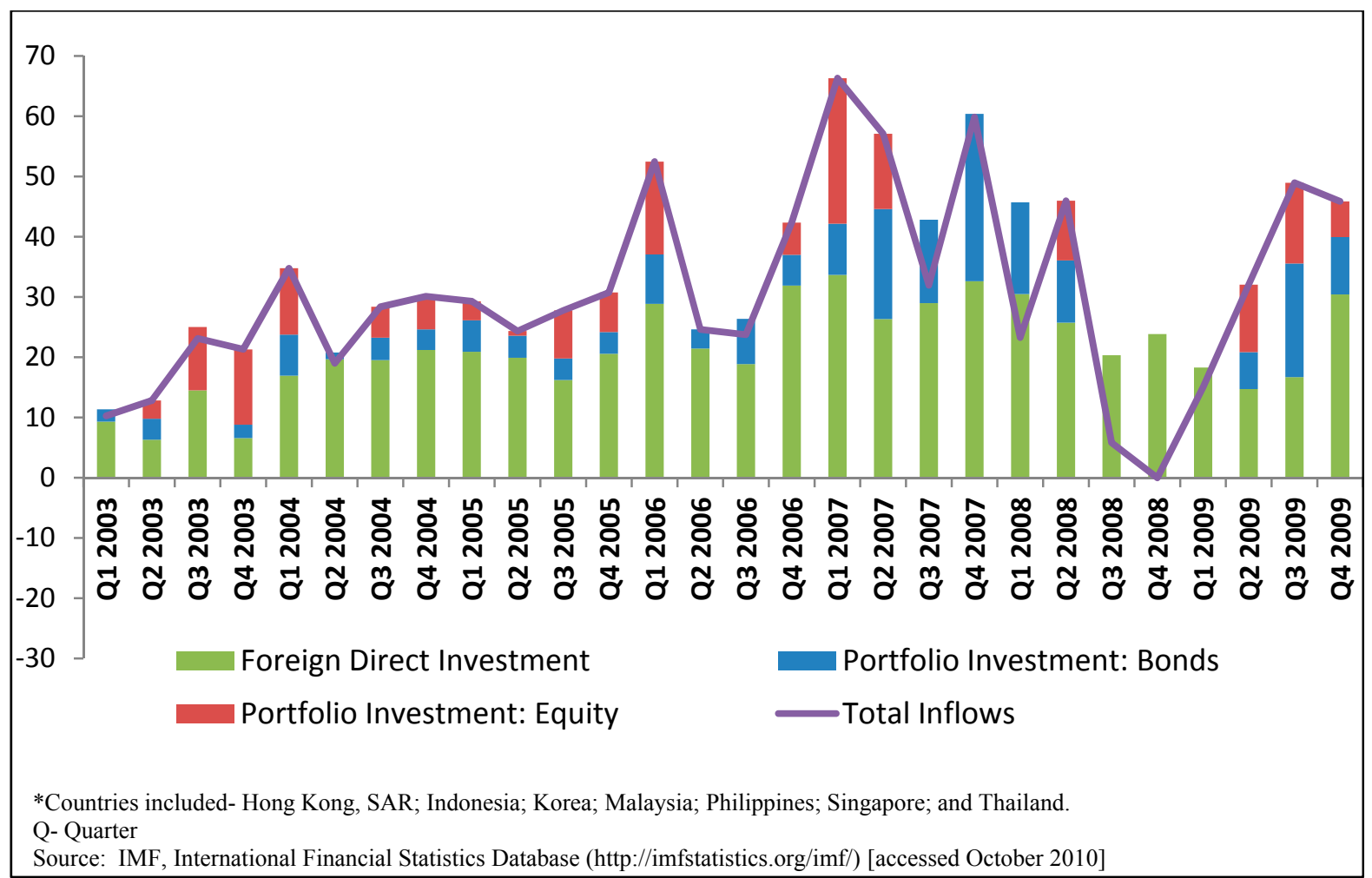

The rapid growth in Asia's emerging domestic bond markets prior to the global crisis was due to the strong growth performance and favorable longer-term prospects for the region (Figure 4). There was a corresponding increase in securities valuation, accompanied by further diversification and globalization of the investor base. Access to Asian capital markets through derivatives instruments (over-the-counter [OTC] derivatives and structured notes) by foreign investors - though difficult to measure - also partly boosted capital inflows prior to the crisis (CGFS (2009)). ${ }^{2}$

\footnotetext{
${ }^{2}$ Foreign investor exposure to domestic assets via (offshore) derivatives may result in capital flows, depending on whether the counterparty to the derivatives position hedges its position in the onshore (domestic) capital market.
} 
Figure 3. Equity and Bond Market Indices

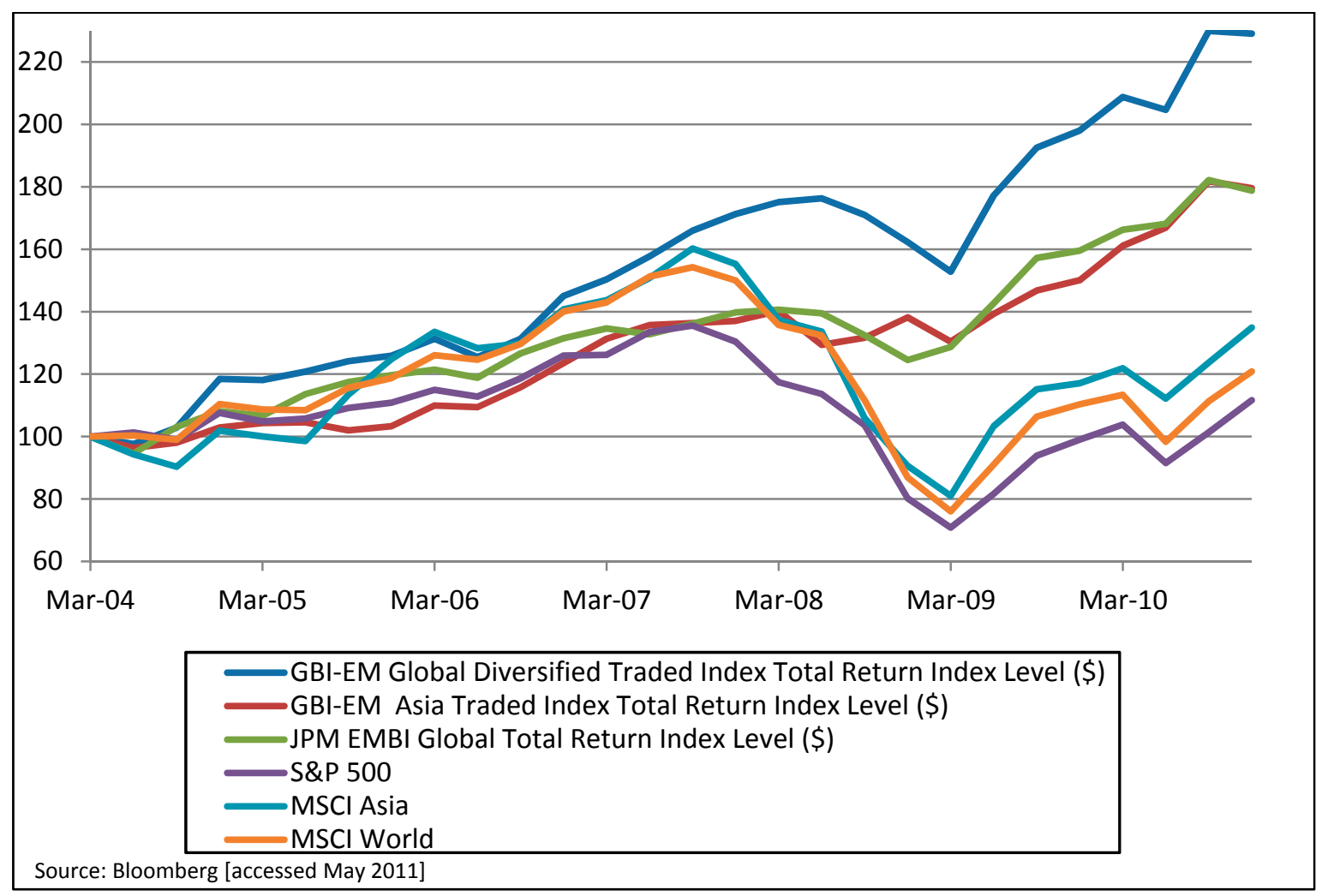

Figure 4. Capitalization of Bond Markets in Emerging and Developing Asia (Percent of Gross Domestic Product)

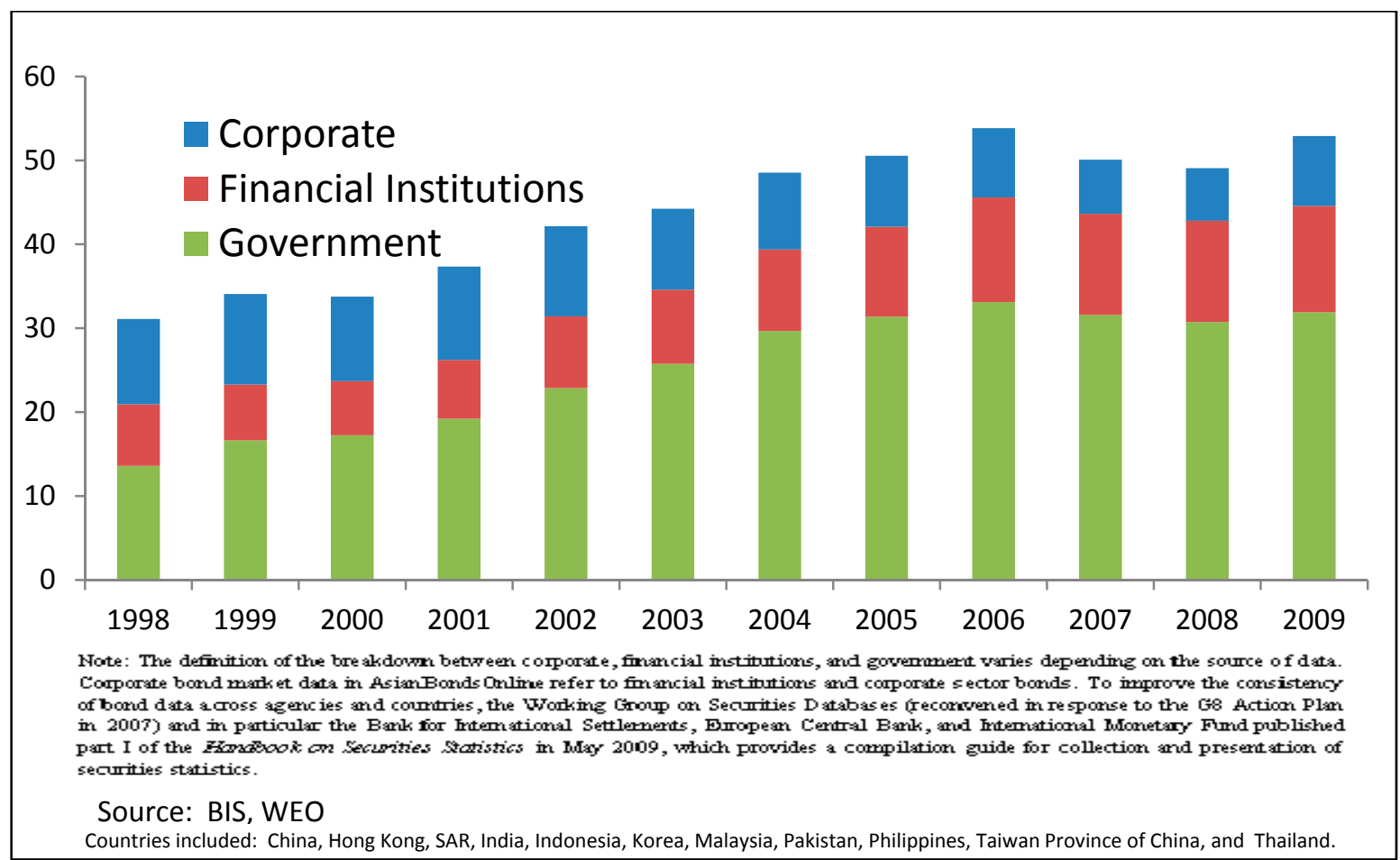


In the last few years, Asian local currency bonds have gained significance in investor portfolios around the world. The emergence of Asian local currency bonds as an asset class has been due to the improvement in the quality of issuers, and the development of market infrastructure and institutions. Asian emerging markets have made notable advancements by creating public debt management units (e.g., Indonesia, Thailand); articulating debt management strategies; and consolidating benchmark issues for building yield curves. Nevertheless, the growth in domestic bond markets has remained largely skewed toward government debt, partly driven by the sterilization needs of Asian central banks during 20022007 for handling the surge in capital flows to the region. Asia's emerging market corporate borrowers continue to be bank-dependent, and though capital market borrowing has increased over the past decade, large firms still find it cheaper and more convenient to raise money in global capital markets. In addition, firms with foreign ownership tend to rely on retained earnings and internal funding from their parent corporations (Mieno et al (2009)).

This paper assesses the progress made in developing local debt markets in emerging Asia. The next section looks at the state of play in local currency debt markets. Section III discusses the main obstacles to further development. Section IV suggests some policy responses, and the last section concludes.

\section{The State OF DeVElopment}

The development of local debt markets in Asia is assessed by examining three key dimensions of market development: (i) the hurdles confronting players and institutions that are or could be borrowers and lenders, (ii) the issues faced by current and potential liquidity providers, and (iii) the presence or absence of supportive government policies and regulations. $^{3}$

\section{A. Borrowers and Lenders in the Local Markets}

Prior to the recent global financial crisis, emerging market external bond issuance increased significantly as banks and corporations improved their access to global capital markets. This improvement was driven by decreasing costs of foreign currency-denominated bond issuance in G3 currencies (U.S. dollar, euro, and yen), favorable credit ratings including transitions to investment grade, and the desire for diversification in terms of currency denomination-from the US dollar to euro, yen, and in some cases domestic currencies.

For most borrowers in Asia's emerging markets, the cost of borrowing is still the primary determinant of the mode of financing, although maturity and diversification of financing sources are becoming increasingly important considerations. In most markets, domestic bond

\footnotetext{
${ }^{3}$ For a more elaborate discussion, see Chami, Fullenkamp, and Sharma (2010). Their approach is anchored in studying the incentives facing the key players in financial markets - borrowers, lenders, liquidity providers, and regulators - whose actions shape markets. Different financial instruments embody different compromises between borrowers and lenders. Identifying the obstacles that prevent the key players from creating, executing, trading, or enforcing particular financial contracts can provide guidance for designing policies that facilitate the functioning and development of markets.
} 
issuance remains costly and cumbersome compared with bank lending. Even governments often issue for short-term, tactical reasons rather than for medium-term strategic objectives that take account of costs, maturity structure, and rollover risk. Corporate finance is dominated by bank-based intermediation, which is still largely relationship-based. ${ }^{4}$ In addition, many of the Asian corporations that resort to bond financing prefer private placements since it allows them to save on the regulatory costs (e.g., registration, prospectus, disclosure requirements) of public listings. ${ }^{5}$

Figure 5. Selected Asian Bond Markets

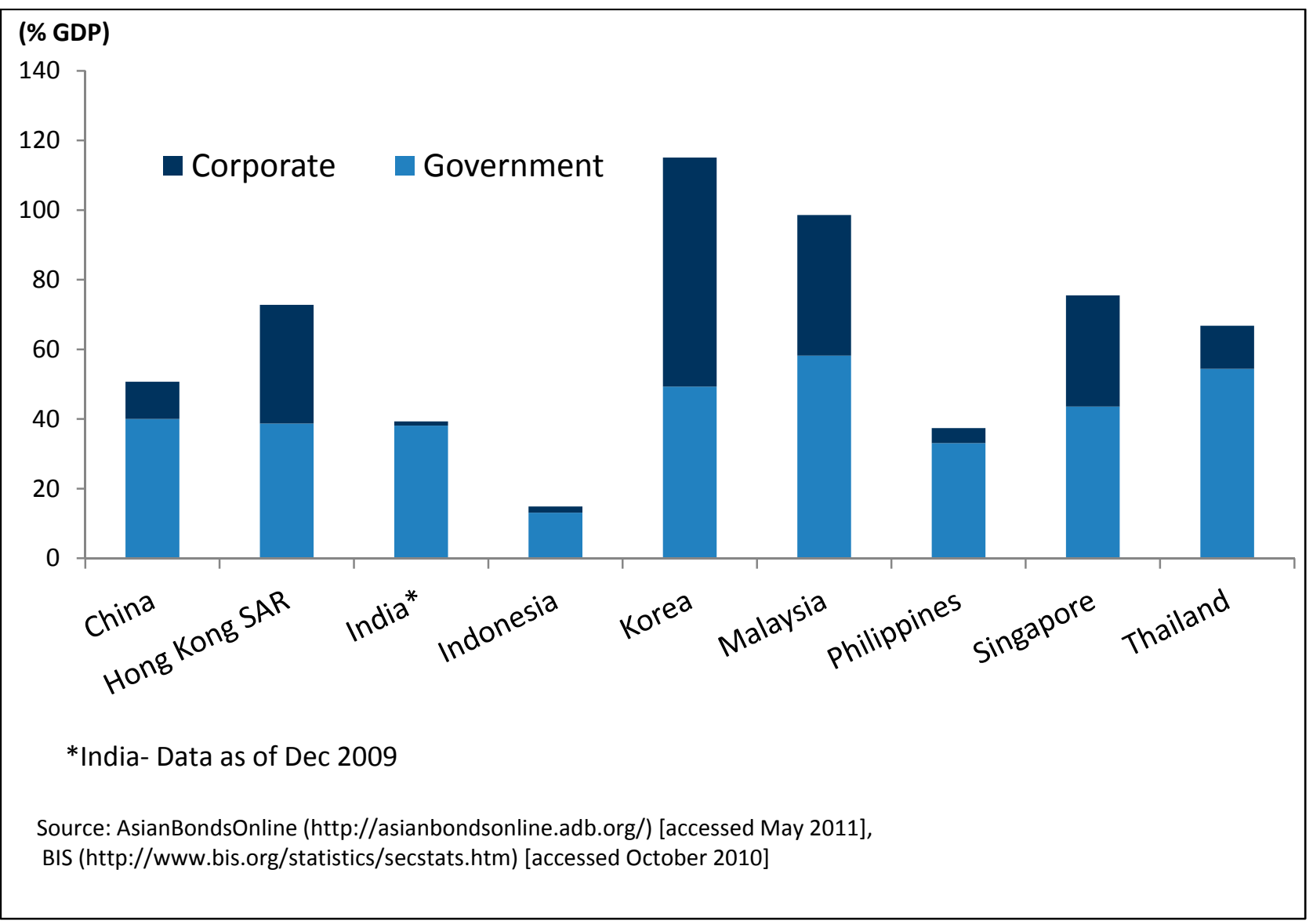

The development of corporate bond markets in Asia remains uneven. Those in Hong Kong SAR, Korea, Malaysia, and Singapore are the largest and relatively the most developed,

\footnotetext{
${ }^{4}$ External wholesale funding relies heavily on intermediation by international banks.

${ }^{5}$ The downside of private placements is the narrower investor base that is largely limited to a few sophisticated investors. In practice, private placements are close substitutes for loan syndication and can be cost-effective for meeting large financing needs that may be beyond the balance sheet capacity of a single bank.
} 
while those in India, Indonesia, the Philippines, and Thailand have lagged behind (Figure 5). ${ }^{6}$ China has experienced significant growth in bond market capitalization since 2005, with a substantial increase in commercial paper issuance and the establishment of a medium-term note market. However, the corporate bond market in China remains small and represents only 8-9 percent of the gross domestic product. Rapid growth in corporate bond markets was also recorded in India and the Philippines, although these markets are still small compared to the overall bond markets.

The investor base in Asia has become broader and deeper with the emergence of domestic institutional investors (Ghosh (2006); Asia-Pacific Economic Cooperation Forum (2008)). Demographic changes, pension reforms, and the larger role played by nonbank financial institutions have supported this development. Malaysia and Singapore have accumulated sizeable assets under their publicly managed pension funds. Such fully-funded pension systems are of particular relevance as they tend to favor debt securities carrying low default risk and they are denominated in domestic currency (CGFS (2007a)). Pension fund assets also grew rapidly in Korea (47 percent per annum during 2002-2007), and the National Pension Fund increased to over 21 percent of gross domestic product in 2007. Most of the National Pension Fund funds are invested in fixed-income securities, mainly government bonds. Pension fund assets in China, India, and Thailand are growing but still remain small (Figure 6[a]).

Growth in the mutual fund industry throughout Asia has been broad-based. Mutual funds have allowed households to hold local currency bonds in more liquid and easily tradable units. Since mutual funds tend to trade actively in response to changes in market conditions, they have brought additional liquidity to local markets (Turner (2009)). Hong Kong SAR and Singapore lead this industry because of their role as regional financial centers, with more than 50 percent of their assets (Figure 6[b]) derived from abroad (Securities and Futures Commission (2010); the Monetary Authority of Singapore (2010)). The rapid growth of mutual funds in other Asian economies such as China, India, Korea, Malaysia, and Taiwan Province of China has been largely dependent on domestic factors. In India, the mutual fund industry has grown from about $\$ 30$ billion in 2004 to more than $\$ 150$ billion (Figure 6[a]) as of the end of May 2010 (Goldman Sachs (2010)). Nevertheless, mutual funds have so far played a limited role in the development of India's corporate bond market, where 80 percent of the debt mutual funds are owned by corporations and retail participation is limited. In addition, corporate bonds account for only 20 percent of the assets in debt mutual funds.

Foreign investor participation in Asian domestic debt markets has been rising, despite setbacks during the global credit crisis (Figure 7). The secular increase in the proportion of their portfolios allocated to emerging market assets by developed country institutional

\footnotetext{
${ }^{6}$ The sukuk (Islamic bond) market, which is outside the scope of this paper, has seen sizeable growth since mid2000, especially in Malaysia.

${ }^{7}$ The data on corporate bonds include issuance by financial institutions.
} 
Figure 6(a). Institutional Assets in Selected Asian Markets
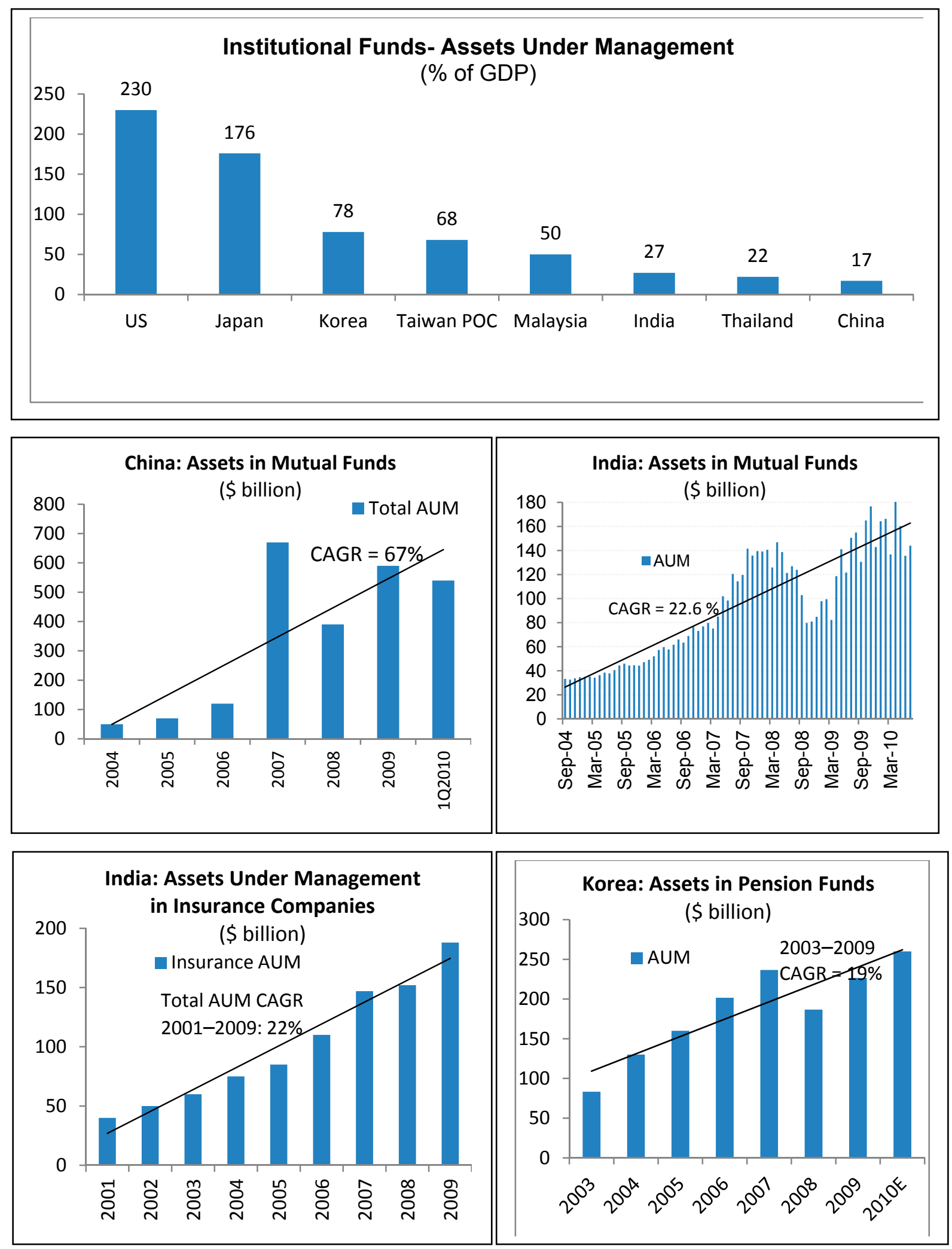

AUM - Assets Under Management; CAGR - Compound Annual Growth Rate.

Source: Goldman Sachs (2010) 
Figure 6(b). Hong Kong SAR and Singapore: Total Assets of Fund Management Industry ( $\$$ billion)

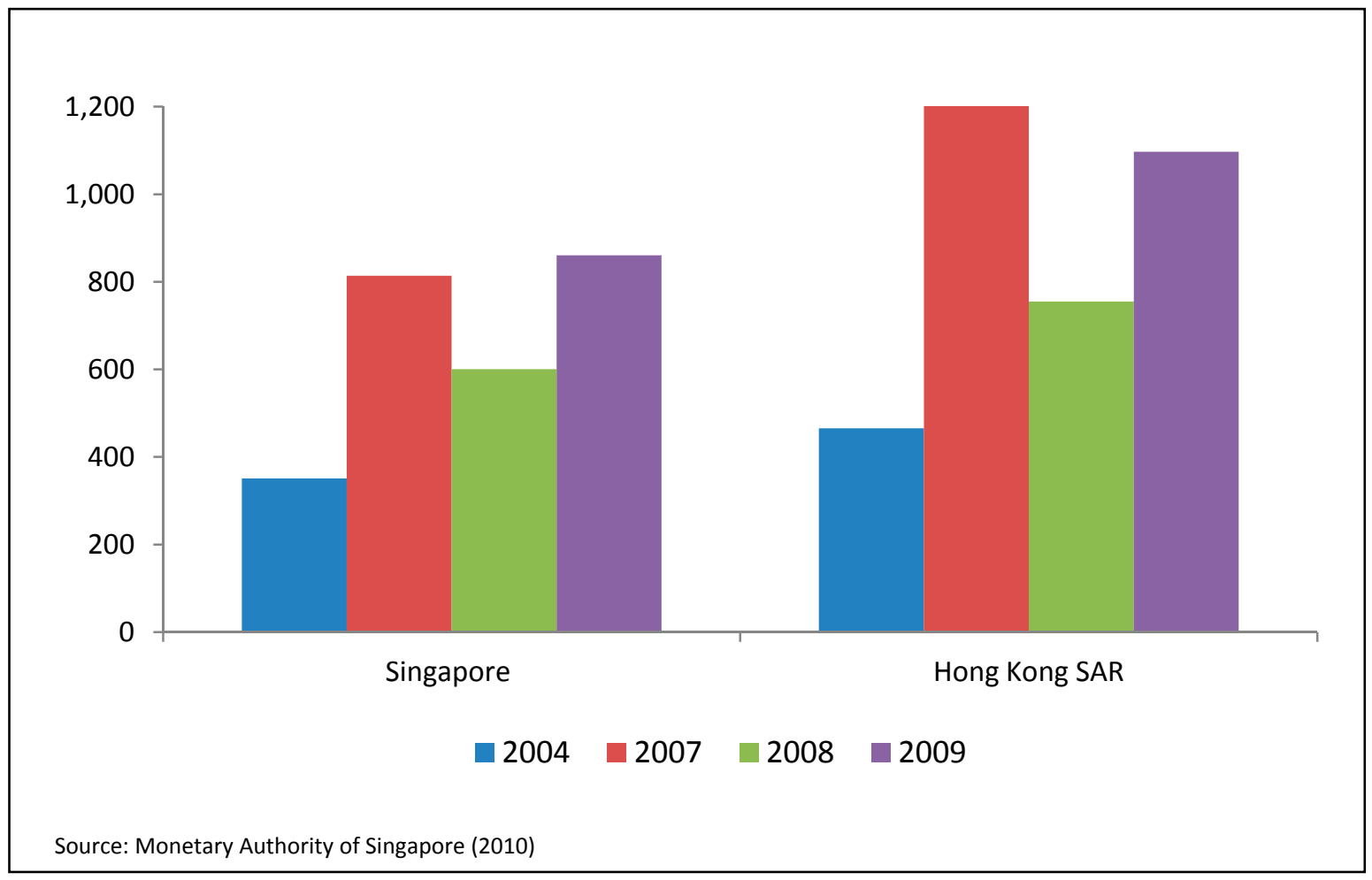

Figure 7. Foreign Holdings of Local Currency Government Bonds (Percent of Total)

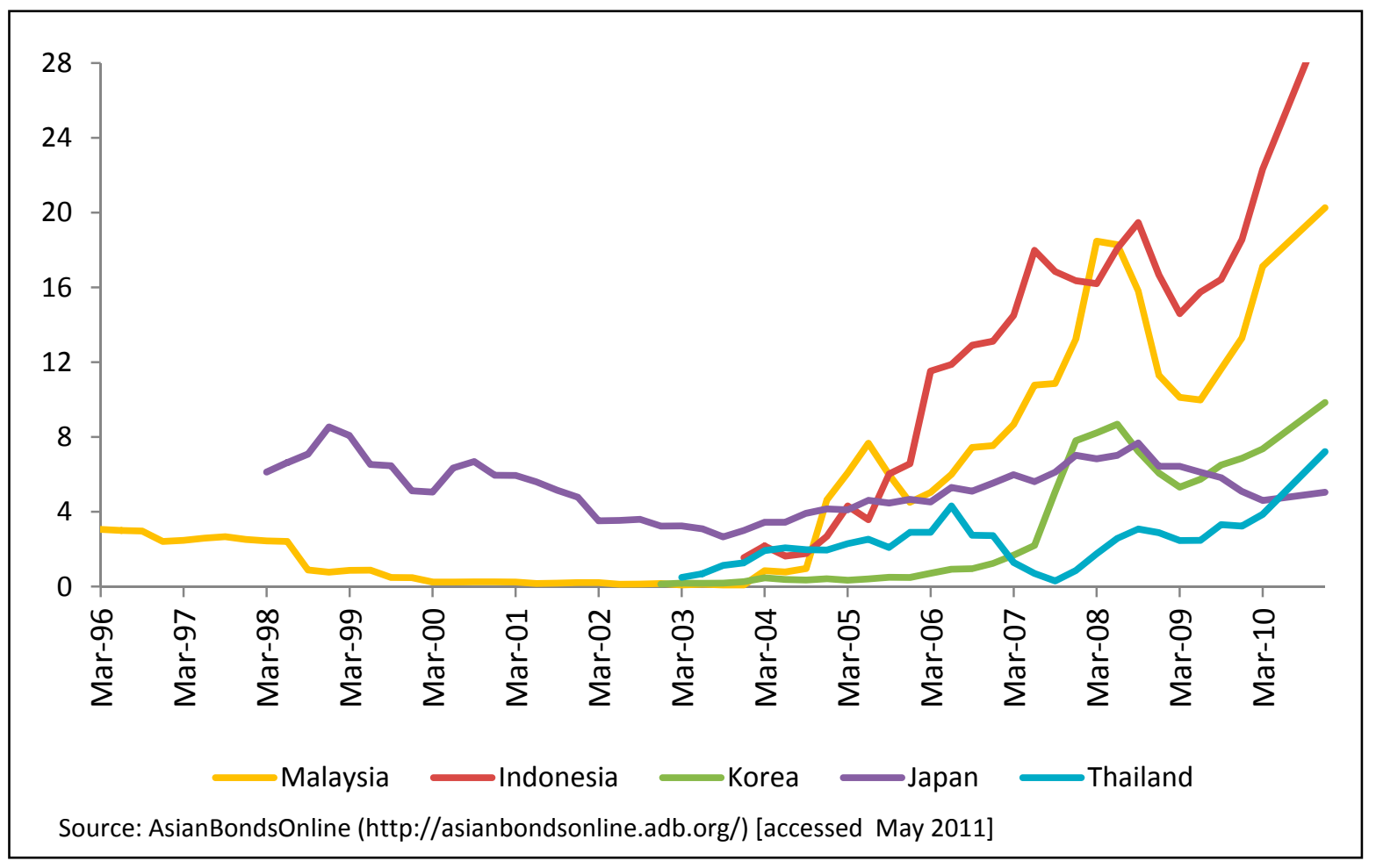


investors has been underpinned by a more favorable risk-return profile, especially during 2002-2007. Foreign participation has largely been through institutional investors such as mutual funds, pension funds, hedge funds, and sovereign wealth funds. Assets under management for dedicated emerging market bond funds, particularly local currency bonds, have risen significantly. ${ }^{8}$ While the global financial crisis led to a decline in foreign investor demand for emerging market assets, most Asian countries have seen renewed foreign interest. Available data may understate the importance of foreign investors, since they also use derivatives (including non-deliverable forwards, structured notes, and total return swaps) to take exposures, which are not easily accounted for.

Regional initiatives by multilateral agencies have also supported the development of local bond markets by reducing impediments to market access (Ma and Remolona (2005)); Executives' Meeting of East Asia Pacific Central Banks (2005)). The launch of the Asian Bond Fund-2 (ABF-2) in March 2005, a regional local currency denominated bond fund, has resulted in the introduction of a Pan Asia Bond Index Fund and a Fund of Bond Funds with eight country sub-funds open to investment by the public. Other initiatives, such as the Asian Bond Market Initiative (ABMI) under the ASEAN+3 framework, have been trying to catalyze the development of local currency bond markets, especially through facilitating the emergence of national and regional market infrastructures for trading bonds. ${ }^{9}$ The ABMI set up working groups to study a number of issues, including the issuance of new securitized debt instruments, the establishment of a regional bond guarantee agency, the creation of a regional settlement and clearance system, and the strengthening of national and regional rating agencies. The recent formation of the Credit Guarantee and Investment Facility, a trust fund of the Asian Development Bank (ADB), is expected to support the issuance of corporate bonds.

The various regional initiatives have resulted in some progress in the development of local debt markets. They have catalyzed tax reforms; changes in regulatory frameworks; liberalization of capital controls; better market infrastructure through the creation of a regional custodial network; harmonized legal documentation for investment funds; and introduced a set of credible, representative, and transparent benchmarks (CGFS (2007)). The Asian Bond Market Forum was set up in September 2010 by the ASEAN +3 countries as a common platform to foster standardization of market practices and harmonization of regulations related to cross-border bond transactions in the region.

Many international financial institutions have raised funds through local currency bonds in emerging markets, including Asian emerging markets, to provide high quality local currency instruments for developing the domestic yield curve. Such activity is leading to the improvement of documentation standards and placement procedures, and helping to attract

\footnotetext{
${ }^{8}$ Data on cumulative net foreign inflows to emerging market equity and bond funds show a rise from less than $\$ 20$ billion in early 2003 to over $\$ 100$ billion by the end of 2009 (Emerging Markets Portfolio Funds Research).

${ }^{9}$ ASEAN +3 refers to countries in the Association of Southeast Asian Nations (ASEAN), and China, Japan, and Korea.
} 
new investors to the local currency markets. The Asian Development Bank, International Finance Corporation, and the World Bank are among the international financial institutions that have issued local currency bonds in various markets, and these instruments have been successful in attracting foreign investors. However, some recent research suggests that firmspecific characteristics are more important for the issuance of public bonds by corporations, with the most important factor being whether the firms had previously issued such bonds. Mizen and Tsoukas (2010) find the effect of local market size and liquidity to be small, and determine that the coordinated policies to encourage bond market development by Asian governments have had little effect on the probability of issuance at the firm level.

\section{B. Liquidity}

Liquidity is essential for financial deepening, and the lack of it continues to be a concern in the developing Asian markets. Secondary market liquidity for an instrument can be facilitated if issuance is sizeable and regular, the trading life of the instrument is sufficiently long, and turnover is large. Liquidity providers can range from dealers and traders to borrowers and lenders themselves. Foreign investors can add to the liquidity in domestic bond markets by widening the investor base and increasing the heterogeneity of market participants. ${ }^{10}$

A better understanding of what drives liquidity is important in enhancing market stability. Liquidity can broadly be measured in two dimensions: (i) macro - the resilience to macro shocks; and (ii) micro - depth, tightness, and the ability to absorb random shocks (Turner $(2007,2008)$ ). The microeconomic indicators are relatively easy to identify. Market depth is the ability to absorb large transaction volumes without a significant change in prices as measured by the average turnover ratios. Tightness implies the cost efficiency and is measured by the bid-ask spreads. The ability to absorb random shocks can be reflected in the day-to-day price volatility. However, the macroeconomic dimension is harder to define empirically. An asset can be more liquid if it tends to hold its value despite a severe shock. For example, a more diversified investor base can make a market, such as the local bond market, more liquid from a macro liquidity perspective.

Liquidity in local bond markets, including those for government debt, varies substantially across Asia's emerging markets (Table 1). The markets in Hong Kong SAR, Korea, Malaysia, and Singapore are the most liquid, and a number of measures have raised prospects for further improvements. For example, constant two-way quotes by primary dealers in Korea have enhanced the liquidity of government securities markets. In addition, the trading of interest rate risk has been greatly facilitated by the development of a liquid Korea Treasury Bond (KTB) futures market. The interest rate swap market in Singapore, with a relatively high average daily turnover, is used as a pricing benchmark by corporate issuers in Singapore dollars. The volume of turnover in the Chinese bond market, especially the corporate segment, has improved substantially since 2005 as a result of the marked increase in the size of the market.

\footnotetext{
${ }^{10}$ See, for example, the discussion in Chami et al (2010).
} 
Table 1. Domestic Bond Market Liquidity Indicators

\begin{tabular}{cccccc}
\hline Country & \multicolumn{2}{c}{ Value Traded (\$ billion) } & \multicolumn{2}{c}{ Turnover Ratio } & $\begin{array}{c}\text { Bid-Ask Spread } \\
\text { (bps) }\end{array}$ \\
& Government & Corporate & Government & Corporate & Government \\
\hline China & 5,368 & 1,812 & 0.68 & 1.29 & 5.1 \\
Hong Kong SAR ${ }^{1}$ & 5,527 & 13 & 32.48 & 0.04 & 4.3 \\
Indonesia & 40 & 2 & 0.18 & 0.06 & 26.6 \\
Japan & 44,907 & 277 & 1.36 & 0.08 & n.a. \\
Korea & 1,347 & 363 & 0.81 & 0.19 & 1.1 \\
Malaysia & 221 & 18 & 0.59 & 0.06 & 2.3 \\
Philippines & 76 & n.a. & 0.38 & n.a. & 6.6 \\
Singapore & 204 & n.a. & 0.65 & n.a. & 2.9 \\
Thailand & 368 & 5 & 0.83 & 0.04 & 3.4 \\
& & & & & \\
\hline
\end{tabular}

1/ Includes Exchange Bills.

bps- basis points

Source: AsianBondsOnline (http://asianbondsonline.adb.org/) [accessed September 2010]

Less liquid markets are generally characterized by a narrow investor base, insufficient infrastructure, low market transparency, and lack of timely information on bond issuers (Gyntelberg, Ma, and Remolona (2006)). Secondary market liquidity can be improved by having an enabling institutional structure ranging from effective trading platforms to the market-making ability of primary dealers. Some countries such as China, Indonesia, and Thailand have undertaken reforms of their market microstructure by establishing marketmakers, introducing modern trading platforms, and upgrading the payment and settlement systems. Despite these structural reforms and an increase in market transparency, trading is often still bunched in certain maturities-leading to market segmentation. This, coupled with a concentration of buy-and-hold investors in domestic bond markets, continues to inhibit liquidity. Secondary market liquidity in many Asian markets is still very much dependent on foreign investors. While access via offshore derivatives markets, notably by foreign banks, can enhance liquidity, it can also lead to the sudden drying up of liquidity when foreign investors withdraw during periods of heightened global risk aversion. 


\section{Regulation}

Policy and regulatory reforms since the Asian financial crisis have supported the development of local bond markets in Asia. ${ }^{11}$ Regulatory and supervisory capacity has been enhanced, while a more supportive environment for capital market development has been fostered. Since 2000 , corporate governance practices have gradually improved, and governments have been more proactive in pushing the reform agenda:

- In China, locally-listed banks have been allowed to buy and sell bonds on the stock exchanges on a pilot basis since January 2009, and corporations (including foreign firms) have been given permission to issue securities in the interbank bond market. Recently, the use of the renminbi as a trading and settlement currency in Hong Kong SAR has been liberalized.

- To improve liquidity and price transparency, Hong Kong SAR launched an electronic trading platform for government and corporate bonds in December 2007.

- In January 2009, India increased the limit on foreign institutional investors (FIIs) for the purchase of Indian rupee-denominated corporate bonds from $\$ 6$ billion to $\$ 15$ billion. The Reserve Bank of India Act was amended in January 2009 to develop and regulate the market for corporate bonds. A foreign exchange swap facility was put in place for public and private sector banks with foreign branches or subsidiaries. The limits on Indian mutual funds for overseas investments were also further liberalized.

- In July 2008, Indonesia set up a bond pricing agency to provide reference prices for government and corporate bonds. Reserve requirements on foreign currency deposits were also eased from 3 to 1 percent in October 2008.

- In December 2008, the Government of Korea established a Won 10 trillion bond market stabilization fund to foster the development of the market. The "Regulation on Supervision of Securities Business" was amended to facilitate exchange and offexchange securities trading, and to attract foreign investors to the bond market. Transparency in the pricing of bonds was also enhanced by requiring securities companies to report standardized bids and offers for all off-exchange traded bonds in real time to the Korea Securities Dealers Association. The authorities also changed the tax laws to reduce taxes on high-yield funds that invest 10 percent or more of their assets in speculative-grade corporate bonds. Korea removed withholding taxes on interest income and capital gains in May 2009. ${ }^{12}$

\footnotetext{
${ }^{11}$ Asia Bond Monitor (2010a, 2010b).

12 To guard against destabilizing capital inflows, the Korean parliament is considering a proposal to reinstate the tax paid by foreigners (foreign corporations and nonresidents) on interest income and capital gains from Korean government bonds.
} 
- Starting in December 2008, Bursa Malaysia waived the listing fees (until 2010) for debt securities denominated in ringgit and foreign currencies. The authorities implemented a phased liberalization of foreign exchange by loosening the limits on residents pertaining to foreign currency and ringgit-denominated credit facilities, and foreign currency and ringgit borrowing. Financial liberalization measures (new banking licenses, foreign strategic partnerships in banking and insurance with higher foreign equity limits, and greater operational flexibility for locally-incorporated foreign financial institutions) have also facilitated foreign participation in domestic capital markets.

- Despite largely running fiscal surpluses and having a very low net debt position, the Government of Singapore has issued debt to help develop the yield curve. In July 2009, the Monetary Authority of Singapore (MAS) took regulatory measures to encourage AAA-rated issuance in the Singapore dollar bond market. First, AAA-rated Singapore dollar denominated debt securities issued by sovereigns, supranationals, and sovereign-backed corporations were accepted as collateral for borrowings from the MAS Standing Facility. Second, banks were allowed to use these securities to satisfy liquidity requirements, while the haircut applied to these securities for repo operations was the same as that for Singapore Government Securities (zero percent). Furthermore, in July 2010, MAS extended the list of eligible securities to include those issued by public entities that were rated AAA and had risk weights of zero under the Basel rules.

- Thailand has allowed foreign governments and financial institutions to issue baht bonds onshore. To encourage Thai corporations to issue bonds, new policies have been adopted that reduce after-tax interest costs and simplify registration procedures. The regulations on the borrowing and lending of securities and short selling have been amended to improve risk management. The Securities Law was revised in 2010 to enhance investor protection as well as the independence, operational flexibility, and supervisory effectiveness of the regulator-the Securities and Exchange Commission. Exchange controls were relaxed on capital flows, notably on holding of foreign currency investments by domestic institutional investors.

While most asset managers in Asian emerging markets do not focus on corporate governance, a small but growing number of institutional investors are beginning to push for improved practices to increase corporate valuations. Improved governance is perceived as essential for having the necessary checks and balances within firms (Kawai (2007)). The development of domestic institutions, especially regulatory agencies, is considered important for defining and enforcing governance standards. Following the Asian financial crisis, governments introduced new regulations to improve corporate governance-including higher disclosure standards (e.g., Thailand); protecting minority shareholders (e.g., Korea and Thailand); and legislative reform of bankruptcy laws (e.g., Indonesia, the Philippines, and Thailand) - but their enforcement remains uneven. A survey conducted in 2006 by The Centre for International Governance Innovation indicated that investor perception of the quality of corporate governance varies significantly across countries. Hong Kong SAR and Singapore were scored to have achieved high standards. Korea, Malaysia, Taiwan Province 
of China, and Thailand were pegged lower. China, Indonesia, and the Philippines were ranked among the lowest in East Asia.

\section{Obstacles to FurTher DeVelopment}

Despite the enlargement of Asian capital markets, challenges remain on several fronts. These include improvements in market access and infrastructure (e.g., market entry, cross-border issuance and investment); transparency; risk assessment and management by financial institutions; the legal and regulatory framework; and market liquidity. The major impediments to growth are (i) bank dominance; (ii) lack of critical size in issuance; (iii) lack of a diverse investor base and preponderance of buy-and-hold investors; (iv) an embryonic legal and regulatory framework for nonbank financial institutions; (v) tax and capital controls on foreign investors; (vi) weak corporate governance; (vii) inadequate information provision, including pricing transparency, and infrastructure issues; (viii) high issuance and transaction costs; (ix) lack of pricing benchmarks and hedging instruments; and (x) lack of a robust framework for asset-backed securitization.

The local investor base in emerging local debt markets is dominated by buy-and-hold investors, generally banks, pension funds, and insurance companies, and the lack of diversity in the investor base is an impediment to greater liquidity in the secondary markets. The low level of trading activity retards the development of profitable market intermediaries and results in high transaction costs, which discourages wider participation. In Asia, bank dominance of the investor base in local bonds has proved detrimental to increasing the average maturity (Figure 8). ${ }^{13}$ While pension fund portfolio diversification has improved in recent years, in many countries asset allocations are still heavily concentrated in government securities. The asset allocation of pension funds has been dictated by regulations on their investments, which follow rigid criteria set by governments. And the resulting concentration of exposures in a particular segment of the market has had a negative effect on liquidity. A well-developed mutual fund industry could raise market liquidity and reduce the hold of bank-dominated intermediation. However, mutual funds in Asia have often not been very well regulated.

Foreign participation in local capital markets of most Asian emerging markets is still constrained by a number of factors. The key impediments (Table 2) include capital controls, taxation, lack of funding and hedging markets, and lack of established benchmark indices (Parreñas and Waller (2006)). In some countries, foreign financial institutions face restrictions compared with domestic competitors on the underwriting of bonds and on derivatives transactions with corporate clients (Asia Securities Industry \& Financial Markets Association (2010)). Countries like China and India allow only licensed FIIs to hold and trade domestic securities. With a couple of exceptions (Malaysia and Singapore), most Asian emerging markets impose withholding taxes on interest earned from local bonds by foreign

\footnotetext{
${ }^{13}$ Bank dominance is more prevalent in Asian emerging markets than in other regions.
} 
investors. ${ }^{14}$ Further, the domestic market for repurchase agreements (repos) is generally not available to foreigners, rendering trading of cash securities very expensive. For example, until recently, foreign investors in Korean bonds had to deal with high withholding taxes and cumbersome procedures for accessing the market, although tax treaties with several countries provided some relief. Taxes have a significant impact on cross-border investment and issuance (ADB (2010c)). In addition, the rationale for imposing withholding taxes on income earned by foreigners may be eroding, as emerging markets swing from being net capital importers to becoming net capital exporters.

Figure 8. Investor Profile for Domestic Government Bonds (In Percent)

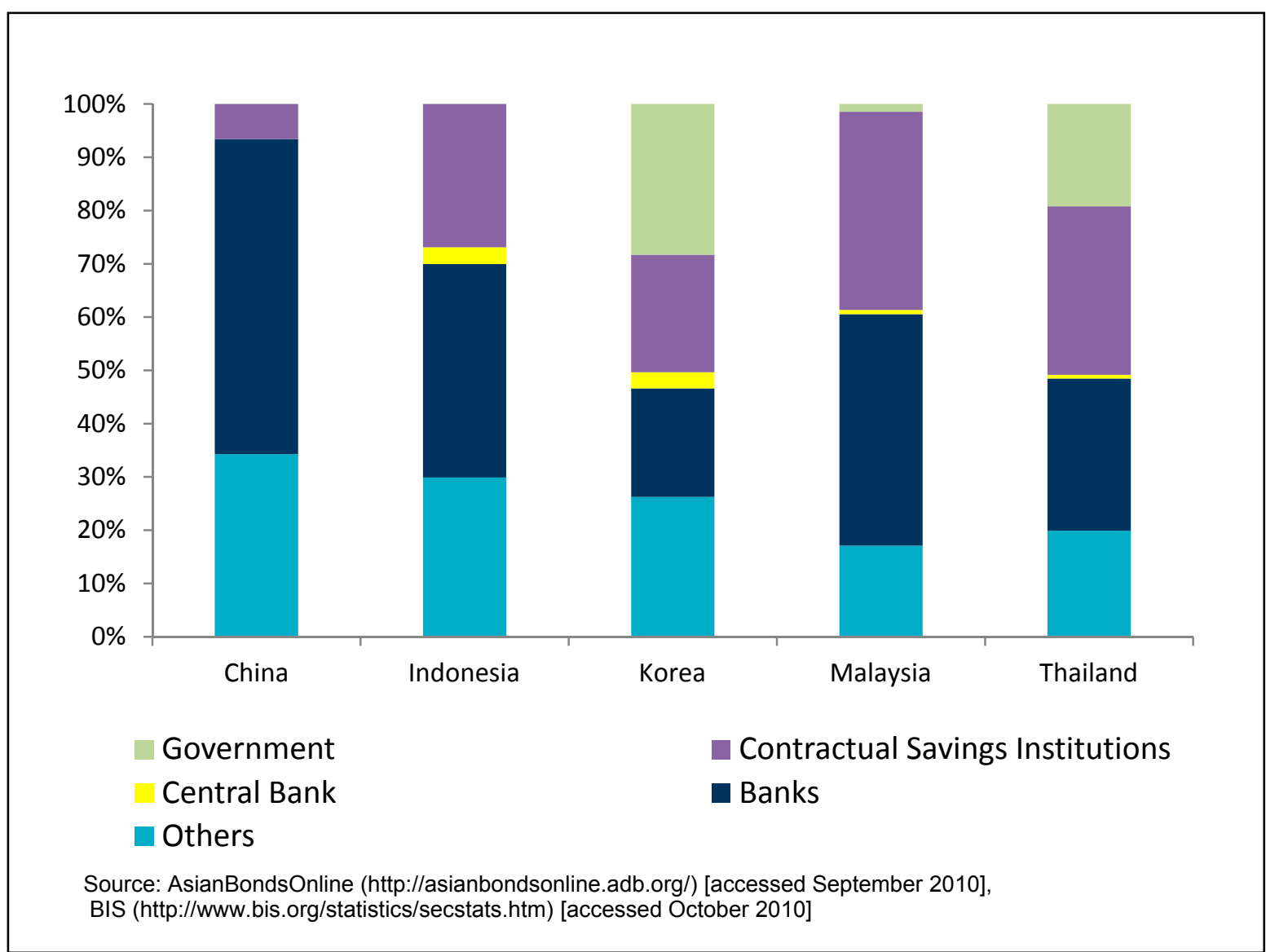

Structural factors, such as the lack of critical size in capital market issuance and the historical dependence on the (now relatively liquid) banking sector, also explain the weak growth of corporate bond markets in Asia (Eichengreen and Luengnaruemitchai (2004); Eichengreen, Borensztein, and Panizza (2006)). The average size of corporations in emerging markets is

\footnotetext{
${ }^{14}$ Thailand, which had exempted foreign investors from withholding taxes on government bonds since late 2005, removed the exemption in October 2010 to deter capital inflows and the appreciation of the baht.
} 
much smaller than in advanced countries, making bonds a less viable financing option, since the fixed costs associated with raising funds through bonds (especially publicly listed bonds) make it a more expensive alternative. The small size also leads to lower levels of market activity for intermediaries and less liquidity, which adds to the cost of issuance. In such an environment, local corporations (especially large ones) are more likely to tap lower cost external bond markets or make private placements.

Table 2. Accessibility, Taxation, Funding and Hedging

\begin{tabular}{|c|c|c|c|c|c|c|c|c|c|}
\hline & China & $\begin{array}{l}\text { Hong Kong } \\
\text { SAR }\end{array}$ & Korea & India & Indonesia & Malaysia & Philippines & Singapore & Thailand \\
\hline Holding and buying local bonds & Limited & Yes & Yes & Limited & Yes & Yes & Custodian & Yes & Limited \\
\hline Non-resident access & Via QFII & Yes & Yes & Via FII & Yes & Yes & Yes & Yes & Yes \\
\hline FX restrictions & Yes & No & No & Yes & Yes & Very Few & Yes & No & Yes \\
\hline Withholding tax (non-residents) & Only corp & No & Yes & Yes & Yes & No & Yes & No & Only corp \\
\hline Capital gains tax (non-residents) & No & No & Yes & Yes & Only corp & No & Only corp & No & Only corp \\
\hline \multicolumn{10}{|l|}{ Funding / hedging instruments } \\
\hline Developed Repo Markets & Yes & Yes & Yes & Yes & Limited & Yes & No & Yes & Limited \\
\hline \multicolumn{10}{|l|}{ OTC Instruments } \\
\hline IRS & Yes & Yes & Yes & Yes & Yes & Yes & Yes & Yes & Yes \\
\hline FX Swaps & Yes & Yes & Yes & Yes & Yes & Yes & Yes & Yes & Yes \\
\hline FX Forwards & Yes & Yes & Yes & Yes & Yes & Yes & Yes & Yes & Yes \\
\hline \multicolumn{10}{|l|}{ Exchange Traded Instruments } \\
\hline IR Futures & No & Yes & Yes & No & No & Yes & No & Yes & No \\
\hline FX Futures & No & No & Yes & No & No & No & No & No & No \\
\hline Liquid NDF market & Yes & No & Yes & Yes & Moderate & Moderate & Moderate & No & No \\
\hline Up to 12 Months & Yes & - & Yes & Yes & Moderate & - & Moderate & - & - \\
\hline Up to 5 Years & Limited & - & Yes & Moderate & Illiquid & - & Limited & - & - \\
\hline
\end{tabular}

Source: Barclays Capital, JPMorgan, Deloitte \& Touche, Price Waterhouse Coopers, BIS, WFE, Asianbondsonline.com, local governments and exchanges.

Legal uncertainties have also thwarted the development of corporate bond markets. Countries with stronger institutions that receive high scores on the rule of law and creditor rights tend to have more developed local currency bond markets (Burger and Warnock (2006)). Despite the widespread reform of bankruptcy laws after the Asian financial crisis, most Asian countries - with a few exceptions such as Korea, Hong Kong SAR, Malaysia, and Singapore - still do not have reasonably robust bankruptcy frameworks that meet international standards in terms of bankruptcy processes, creditor rights, and investor protection (Figure 9). For example, in China the legal framework for the enforcement of creditor rights, especially in the case of bankruptcy, inhibits the carrying out of close-outnetting. ${ }^{15}$

\footnotetext{
${ }^{15}$ Close-out netting in relation to OTC derivative transactions is the ability of a party under a master agreement (such as an ISDA Master Agreement) to net the mark-to-market values of all existing transactions under the master agreement upon their early termination following the default of its counterparty (or some other specified events).
} 
Figure 9. Domestic Bond Markets and Impediments to Contracting

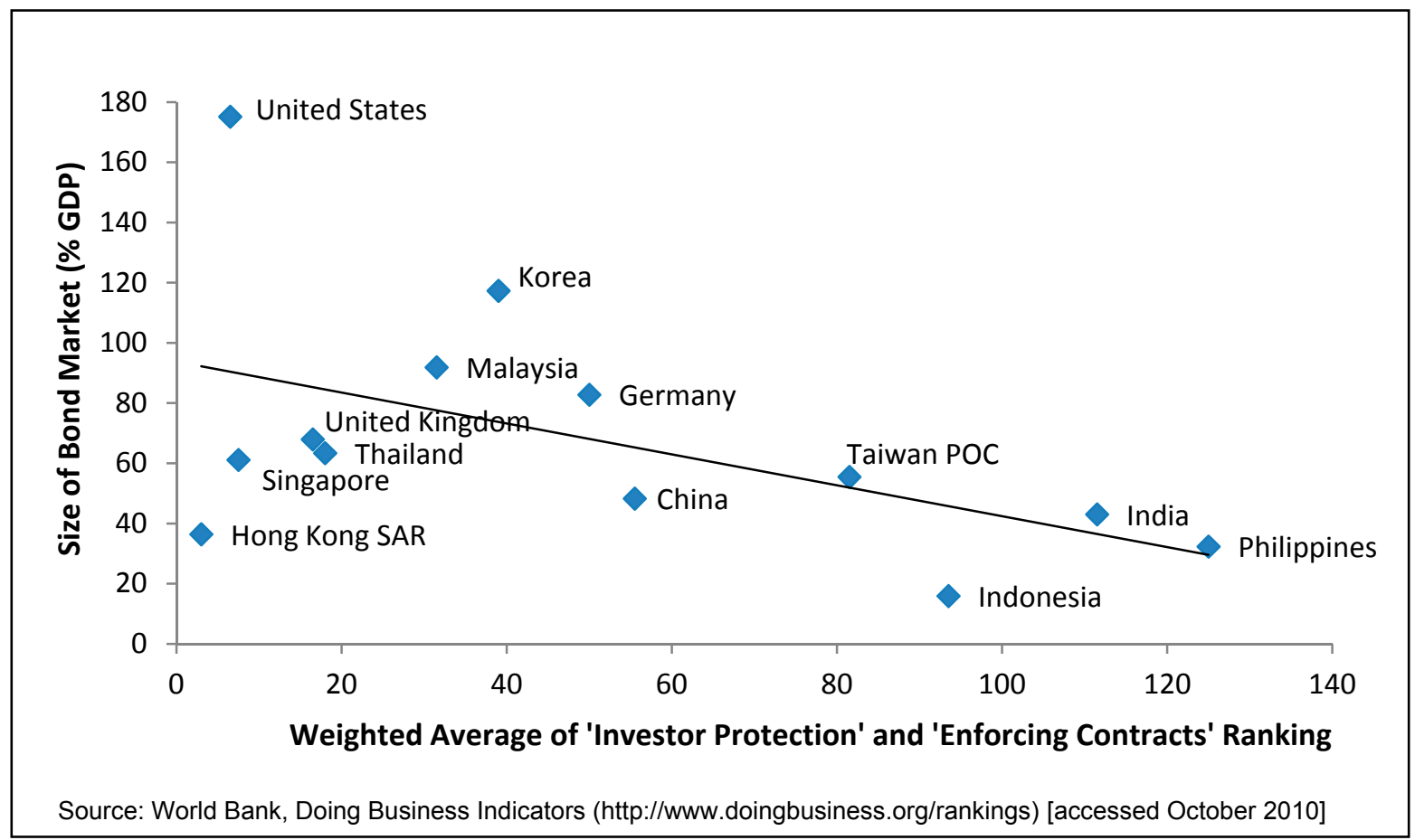

In most Asian countries, corporate bond markets are underdeveloped and/or illiquid as a result of fragmentation, high transaction costs, and the lack of government yield curves that can serve as benchmarks for pricing and hedging. Even countries with sizable corporate bond markets suffer from low trading volumes and very high transaction costs that inhibit arbitrage and active position taking. For example, turnover ratios of Malaysian and Korean corporate bonds are significantly lower than those of their respective government bond markets. In addition, a significant proportion of the corporate issuance, especially for the quasisovereigns, takes place in the private placement market, where securities are often not rated and are generally held by investors with a higher risk tolerance such as hedge funds.

Benchmarks for emerging market local currency bonds are still being developed. There has been some progress in this area since the launch of JP Morgan's GBI-EM index family, the iBoxx Pan Asia Index, Citibank's World Government Bond Index, and others like the Bank of America-Merrill Lynch Global Government Index. The availability of indices can be an important contributing factor to the potential deepening of local markets, since asset allocations by institutional investors are often driven by investable benchmarks. Higher scores for investable benchmarks (Table 3) - that combine measures of market access, taxation, efficiency, regulation, infrastructure, investor base, instruments, and market sizegenerally foster the participation of institutional investors (International Finance Corporation (2009)). Investments benchmarked to local market indices have increased in the past decade but remain insignificant relative to the size of the markets. Indices encourage the participation of professional asset managers as their performance is gauged against such 
benchmarks, especially by institutions such as pension and mutual funds. ${ }^{16}$ By promoting broader participation, indices can reduce market segmentation of the investor base (Glaessner (2008)). However, local bond market indices such as the GBI-EM are difficult to replicate by most fund managers in a cost-effective way. Large investment banks can more easily reproduce them in-house, for example, by using their local subsidiaries in emerging markets to hold domestic bonds that are not available to foreign investors (J.P. Morgan (2009)).

Table 3. Investability Indicators

\begin{tabular}{|l|l}
\hline A. Market Access & Regulation of outflows \\
& Regulation of inflows \\
& Restrictions on money market \\
Restrictions on bond market & Restrictions on derivatives \\
& Turnover taxes \\
& Short-term taxes \\
& Effective capital gains tax rate \\
& Income withholding taxes \\
& Double taxation treaties \\
& Primary market and issuance cost \\
& Secondary market turnover volume, \% free-float \\
& Liquidity, bid-offer spreads \\
& Legal enforceability of contracts \\
& Effective market oversight \\
& Settlement system and failure rate \\
& Trading system capacity and costs \\
D. Market Efficiency and Regulation & Cost for custodian services \\
& Exchange-traded fixed-income funds \\
Size of domestic institutional investors & Average duration of domestic debt \\
& Share of fixed-rate debt issuance \\
Share of corporate debt issuance \\
Size of hedging instruments (OTC, ETD) \\
Volume of long-term FX derivatives
\end{tabular}

Source: International Finance Corporation [accessed October 2010]

Liquidity in secondary markets is hampered by lack of depth in the repo market. By providing a funding source for investments in government and corporate bonds, and for financing dealer inventories of securities held for trading, repo markets enhance market liquidity. Repos and securities borrowing and lending in many Asian emerging markets are still heavily restricted or simply not available, and this reduces two-way trading in both

\footnotetext{
${ }^{16}$ Benchmark indices are more important for conventional collective investment vehicles that pursue relative performance strategies. In contrast, hedge fund type vehicles that pursue absolute return strategies are less affected by the absence of benchmark indices.
} 
equity and local bond markets. For example, China prohibits the lending of equities, and allows only domestic institutional investors to participate in the repo market. Even in relatively developed markets such as Korea, further simplification of foreign exchange rules is needed to allow foreign investors to finance the holding of government bonds using crossborder repos. Singapore has developed a repo market, but liquidity in the term repo market could be enhanced. The easing of rules and regulations on securities lending by asset managers in Asian emerging markets will have to be carried out in tandem with improved risk management practices and custodial arrangements for collateral.

Derivatives markets in emerging Asia are largely underdeveloped because they face some of the more generic impediments such as transaction taxes, lack of liquidity in cash bond markets, and weak operational infrastructure. Most derivatives in Asia are transacted in the OTC market (Figure 10). Interest rate swap markets in India, Korea, Malaysia, and Singapore are more developed. The development of onshore foreign exchange swap markets in some Asian countries has been limited by capital controls and restrictions on nonresidents. While foreign exchange swap activity is quite substantial in Hong Kong SAR and Singapore, it remains very low in other countries (Table 2). Forward market activity is generally not well developed either. Restrictions on obtaining local currency by foreign investors have led to the development of sizeable and liquid non-deliverable forward markets, notably for China, India, and Korea. On the other hand, all foreign exchange transactions involving the Singapore dollar and the Hong Kong dollar take place in deliverable onshore markets as these countries do not have any restrictions. The derivatives markets outside Hong Kong SAR and Singapore largely have a domestic focus and are not as well developed, with a few exceptions. Exchange-traded interest rate futures are mainly present in Hong Kong SAR, Korea, Malaysia, and Singapore. The government bond futures market in Korea is one of the most liquid derivatives markets in emerging Asia. Exchange-traded and OTC derivative markets elsewhere in the region are relatively small and undeveloped.

Figure 10. Over-the-Counter Derivatives Markets

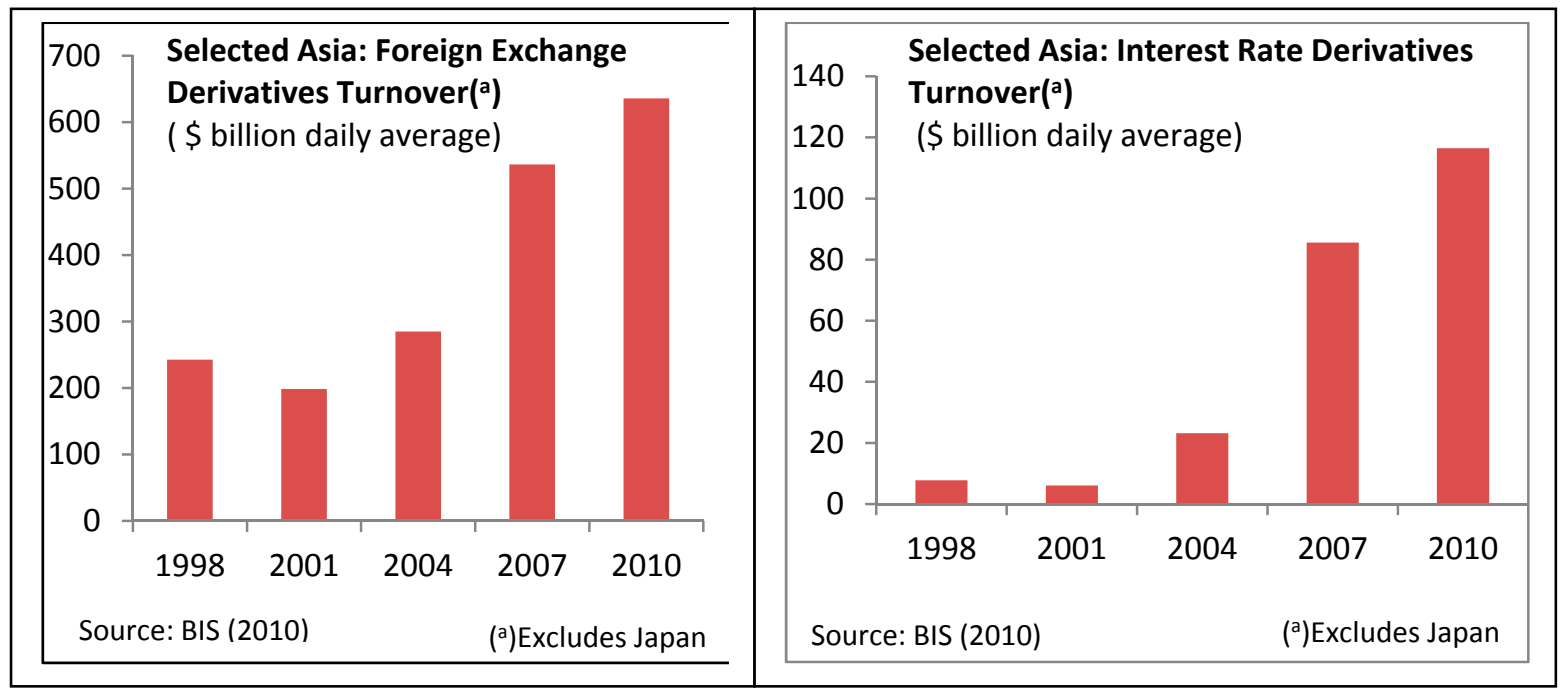


With the exception of a few countries, asset-backed securitization in Asian emerging markets has been subdued. This is mainly because the incentive to securitize is low in financial systems dominated by banks with ample liquidity. Furthermore, alternative savings vehicles are only gradually gaining traction. More recently, the global credit crisis has severely impaired confidence in asset-backed securities (ABS) as regulators, credit rating agencies, and markets reevaluate the whole securitization process. The packaging of residential mortgages has yet to take off in Asian emerging markets, although ABS from auto loans and credit cards had increased somewhat prior to the subprime mortgage crisis. Korea saw the most rapid growth in ABS, mainly from mortgage-backed securities. The expansion in Hong Kong SAR and Singapore was also related mostly to activities associated with residential housing and commercial property.

The hurdles faced in the securitization markets are linked to country-specific factors such as poor legal frameworks, a small investor base, high costs, taxes, lack of transparency, and informational and reporting deficiencies regarding transactions. In the absence of comprehensive securitization laws, the regulatory responsibility for different aspects of the securitization chain is often spread across several agencies. Lack of data to calculate default histories and limited investor awareness and understanding of ABS is also an important issue. For example, India amended its Securities Contracts Regulation Act in 2007 to cover securitized instruments, but several impediments remain. In the absence of a securitization act, taxation and legal uncertainties exist with regard to the securitization vehicle. In addition, the lack of an effective foreclosure law; high incidence of stamp duties in some states; and the generally sparse understanding of the instrument among investors, originators, and even rating agencies, inhibits ABS market development in India.

\section{Policy Recommendations}

The global credit crisis has underscored the need for Asian emerging markets to create deep local currency bond markets as part of a well-diversified financial system. Private and government bond markets are also required for the financing of huge infrastructure needs, and will play a central role in expanding funding channels at a national and regional level, and creating derivatives markets for managing risk (Sheng (2010)). To accomplish this, Asian policy-makers will have to address the lingering structural problems and reorient policies to facilitate capital market development and reform.

The dominance of bank-based intermediation can be reduced by strengthening confidence in the regulatory, supervisory, and enforcement frameworks for capital markets and nonbank financial institutions. As the recent crisis has shown, for capital markets to function effectively, it is critical that sufficient information is available to assess credit risks adequately. A credible rating system, appropriate reporting requirements, and adoption of international accounting standards will help foster market discipline. The overseeing of nonbank financial institutions may have to be rationalized and consolidated to improve effectiveness and reduce the scope for regulatory arbitrage. Countries will have to build the capacity of their agencies to design and implement the rules, and engage in greater crossborder cooperation with counterparts in the region. For example, Korea has adopted a new 
framework for the financial investment industry that consolidates the oversight of all capital market related institutions. ${ }^{17}$ The new framework has taken a functional approach to regulation in which financial functions are subject to the same regulation, regardless of the type of financial institution that performs them.

A reliable benchmark yield curve is critical for developing a liquid corporate bond market. The government securities market can provide such a yardstick for pricing various debt instruments, including corporate bonds. Even governments that do not have financing requirements often build a benchmark yield curve to facilitate price discovery in private debt markets. For example, Singapore, despite generally running a budget surplus, issues government securities to foster the development of a liquid benchmark yield curve. To this end, Singapore lengthened government securities maturities to 15 years, and more recently to 20 years. While Singapore dollar corporate bonds tend to be priced off the swap offer rate, the introduction of government securities has encouraged the development of swaps for longer dated maturities, extending up to 30 years. This has stimulated greater issuance of long-term bonds.

A well-diversified domestic and foreign institutional investor base (pension, insurance, mutual, and hedge funds) can shift financial intermediation from banks to capital markets by increasing the demand for long-term financial assets. Large portfolio holdings of government bonds expose banks to interest rate volatility, and longer-term lending for infrastructure aggravates their maturity mismatches. This calls for greater diversification of income sources of banks (such as fee-based income) coupled with more prudent credit risk assessment. A broad domestic investor base, besides adding to the liquidity and depth of local bond markets, may also serve as an investor of last resort in the case of a turnaround in global risk appetite.

Revamping investment regulation and liberalizing asset allocation restrictions on domestic institutional investors could be crucial for capital market development. In particular, the range of eligible local instruments should be widened and the limits on foreign asset holdings loosened. For example, the relatively long maturity of Korean corporate bonds is largely due to significant holdings (about 30 percent of corporate bonds outstanding) by domestic pension funds and insurance companies. Reforms need to be undertaken in tandem with strengthening governance structures and risk management systems. For the mutual fund industry, regulators have to ensure that investor confidence is maintained through adequate regulation and enforcement, notably in (i) securing the legal basis for the funds; (ii) defining the role of managers and custodians of funds; (iii) disclosing information to investors; and (iv) ensuring transparency in issuance, asset valuation and pricing, and redemption rules of the fund.

Foreign investor participation can benefit the development of local bond markets, especially after the market reaches a certain size. The attractiveness of emerging local bond markets can be enhanced by lowering the cost of access and addressing issues related to taxation and

\footnotetext{
${ }^{17}$ In 2007, the Republic of Korea passed the Financial Investment Services and Capital Market (Consolidation) Act. The new act became effective on February 4, 2009.
} 
capital controls. Such reforms may help draw more stable foreign institutional investors that have a longer-term horizon and are generally not leveraged. The removal of obstacles may also increase foreign participation by increasing the probability of being included in investability indices. For example, in financial hubs like Hong Kong SAR and Singapore, foreign investor access to local currency bonds and the availability of local repo funding has enhanced the liquidity and functioning of these markets.

Foreign investors also pay increasing attention to corporate governance practices. The five key areas of corporate governance as identified by the Institute of International Finance are (i) minority shareholder protection; (ii) the structure and responsibilities of the board of directors; (iii) accounting and auditing; (iv) transparency of ownership and control; and (v) a regulatory environment that creates a credible foundation for corporate transparency, good accounting practices, and protection of shareholder rights.

A pivotal factor for the growth of Asian corporate bond markets is likely to be the lowering of costs, and the ease with which borrowers can tap the markets. For example, in Singapore, prospective issuers face almost no legal, regulatory, or tax impediments. Disclosure documents are quite simple and tend to be streamlined, and bond terms are relatively standardized and are broadly in accordance with International Capital Market Association guidelines. Many foreign banks and insurance companies, and other offshore issuers with high credit ratings and/or strong name recognition, have issued medium-term notes and longterm debt instruments.

Pricing transparency and improvements in trading mechanisms and custody and settlement systems can play an important role in enhancing liquidity and efficiency, while reducing trading costs and volatility. In Hong Kong SAR, one of the most liquid Asian bond markets, the Hong Kong Monetary Authority launched the Central Money Markets Unit Bond Price Bulletin website in January 2006, providing retail investors with convenient online access to indicative bond prices quoted by major banks. India now requires all debt trades, including private placements, to be reported on a standardized platform. More countries in Asia could also adopt the practice of allowing local currency debt to be traded through international clearing and settlement systems such as Euroclear and Clearstream. In Asia, market-makers consider that enhancing the diversity of the investor base is the single most important factor for increasing liquidity. The other factors they mention are (i) the availability of hedging products, (ii) functioning repo markets, (iii) price transparency, (iv) tax incentives, and (v) efficient clearing and settlement systems. Active liability management by corporations and financial institutions would also go a long way in supporting liquidity in the markets.

Skillful sovereign debt management could consolidate issuance along chosen segments of the government yield curve to enhance liquidity and develop a benchmark curve for longer tenors. Price discovery and liquidity in government bond markets can be improved by timely and regular provision of information, and by reopening of longer-dated government benchmark issues. ${ }^{18}$ In certain cases, developing the interest rate swap market (e.g.,

\footnotetext{
${ }^{18}$ The withholding tax rates for FIIs are typically 10\%-20\% for most Asian emerging markets, but tax treaties generally bring the rates down to about 5\%-15\%. Often, market participants find even a $10 \%$ withholding tax
}

(continued...) 
Singapore) could provide a suitable pricing benchmark for corporate sector issuance. The ability of market participants to take advantage of arbitrage opportunities would also help establish proper linkages between cash, money, and capital markets.

As in more developed local markets, a comprehensive package of reforms dealing with market micro-structure can significantly enhance secondary market liquidity in government bond markets. ${ }^{19}$ These measures include (i) auction schedules, (ii) bond reopening schemes, (iii) new regulations on repo and securities lending markets, (iv) Separate Trading of Registered Interest and Principal Securities (STRIPS) programs for government securities, (v) exchange programs for redeeming high interest floating-rate bonds for newly issued fixed-rate bonds, and (vi) buyback programs for government securities (OECD-World Bank-IMF Global Bond Market Forum 2008).

The development of local bond market indices can facilitate trading of local currency bonds and allow investors to track performance. This is likely to attract asset managers that pursue active trading strategies and perhaps lead to increased participation by a more diverse array of investors, including institutional and foreign investors. Indices also offer incentives for emerging markets to reduce impediments so that they are included in an index. For instance, the JP Morgan GBI-EM (Narrow) index limits inclusion to countries that are readily accessible and have few regulatory and tax impediments for foreign investors.

The markets for simple derivatives can be developed in parallel with the underlying cash bond markets. Derivatives markets rely on the existence of underlying assets, so it is reasonable to initiate development after the markets for the underlying cash securities exist and are reasonably liquid. However, waiting until the markets for the underlying assets are fully developed may not be optimal. In the largely OTC derivatives markets in Asia, participants bear high counterparty risks and bilateral clearing costs. Besides, these markets are more difficult to monitor and regulate. Following the example of Brazil and the regional financial centers (Hong Kong SAR and Singapore) that have exchanges for interest rate futures, the larger Asian countries should develop exchange-based trading of foreign exchange and interest rate derivative products. ${ }^{20}$ This would facilitate not only liquidity and price discovery, but also lead to more efficient netting and use of collateral, increased transparency, better market surveillance, and lower counterparty risks.

Lessons can be drawn from the more developed markets of Hong Kong SAR and Singapore where the swap markets for foreign currencies, in particular, are both broad-based and liquid. Fostering a liquid swap market in Singapore entailed permitting offshore banks to engage in

large enough to reduce profits substantially since the tax is imposed on gross financial income (before subtracting the cost of funds). Therefore, FIIs that do not have a permanent domestic presence are burdened with taxes on gross income as opposed to the taxes on corporate profits paid by local competitors.

${ }^{19}$ Mexico is a recent example of a country that adopted such reforms.

${ }^{20} \mathrm{BM} \& \mathrm{FBOVESPA}$ in Brazil trades futures and options on foreign exchange, interest rates, stock indices as well as commodities. The inter-dealer derivatives market in Brazil also operates through this exchange. 
local currency swap activities, the phasing out of statutory liquidity requirements on swap transactions of banks with nonbank financial institutions, and allowing securities dealers with adequate risk management systems to play a more active role. The presence of sophisticated corporate treasuries also provided impetus for the development of local swap markets as they actively managed their risk in the domestic markets (e.g., hedging interest rate risk through the interest rate swap market).

There is considerable potential for developing both the covered bonds and ABS markets in Asia. In the aftermath of the global financial crisis in which ABS and structured finance played a major role, development is likely to hinge on rebuilding investor confidence, and the presence of appropriate regulations concerning transparency, disclosure, role of rating agencies, and the proper alignment of incentives. Because of fewer legal and technical challenges compared with ABS, covered bonds may be easier to introduce in bank-based financial systems. For covered bonds, the assets remain on the balance sheet of the banks (or other originators) and, unlike ABS, do not have to be sold to a special purpose vehicle. Since investors have full recourse to the banks that originate the pool of assets, such structures create incentives for the banks to maintain the quality of the underlying pool. That said, while covered bond instruments do not require the legal structures and support services that have to be created for ABS, specific rules to facilitate covered bond issuance will have to be promulgated in Asia's emerging markets. So far, the issuance of covered bonds in Asia has been sparse except for a few issues in Korea.

Securitization in Asia is likely to be eventually driven by the desire to enhance liquidity in the banking system as disintermediation gathers pace, and to meet the funding needs of the real economy rather than balance sheet arbitrage (Arner, Lejot, and Schou-Zibell (2008)). As domestic demand becomes the main engine of growth in Asia's emerging markets and capital market development proceeds, illiquid assets like mortgage and consumer loans could be securitized. This can address the size issue confronting private bond markets while providing institutional investors with a more diverse set of instruments as new assets are created from infrastructure investments, commercial real estate, housing, and household consumption.

The US subprime mortgage crisis has exposed the dangers associated with securitization. By learning from this, Asian countries can adopt a simpler and more robust securitization system. To foster this, market participants, regulators, and other stakeholders will have to build supporting institutions and capabilities to ensure strong prudential norms for origination, capital adequacy, liquidity, valuation, and special purpose vehicles. Therefore, comprehensive securitization laws, lower tax and registration impediments for securitized transactions, investor education on securitization, and stronger foreclosure norms (especially on mortgages) could help provide the foundation for an ABS market. For example, Korea, where securitization has had a reasonable degree of success, introduced new laws after the Asian financial crisis, which introduced the legal framework for creating special purpose vehicles and facilitated the "true sale" of assets to bankruptcy-remote entities. Countries like the Philippines, Taiwan Province of China, and Thailand have either enacted new legislation for securitization or are close to passing the laws.

Last but not least, data collection and reporting systems not only for borrowers but also for investor holdings should be improved. Databases should provide information on primary and 
secondary market size, maturity structure, and liquidity. Creation of a centralized database on all corporate bonds issued and outstanding would significantly increase the flow of information. Adoption of the methodological standards suggested in the recently published Handbook on Securities Statistics prepared jointly by the Bank for International Settlements (BIS), the European Central Bank (ECB) and the International Monetary Fund (IMF) would go a long way toward advancing domestic market surveillance and contributing to the harmonization and development of regional platforms (Deutsche Bundesbank, IMF, and the World Bank (2009)).

\section{CONCLUding REMARKS}

The key challenge in Asia is to generate financial assets in line with its economic growth that can provide the underlying collateral for expanding fixed-income markets and hence domestic and regional investment opportunities. Shortage of good quality financial assets can lead to speculative valuations in emerging markets and contribute to global imbalances (Caballero 2006). A significant proportion of Asian corporations have credit ratings below investment grade. Besides inhibiting issuance, the low ratings preclude certain investors from having these assets in their portfolios. However, with growth in residential mortgages and other household debt instruments, the region has the potential to substantially broaden and deepen the collateral pool available for underpinning regional and local fixed-income markets.

The issue of critical size could be addressed through an integrated regional market for local currency bonds that provides greater scale, efficiency, and access. Regional cooperation through ASEAN+3, ABMI, and ABFs could be used to catalyze improvements in bond markets and increase financial market integration (Kawai (2007)). Though difficult, especially given the heterogeneity of issuance jurisdictions, Asian emerging markets have to work further toward harmonizing market infrastructure, notably in trading and clearing platforms, custody arrangements, as well as in standardizing valuation rules. To this end, countries should continue to raise domestic standards in line with international best practice. Furthermore, incentives at the firm level must also be examined to assess why bond finance is not yet an attractive option in many countries. Much of it could be due to inertia stemming from a historical dependence on bank finance, high costs of bond issuance, and lack of familiarity with the processes and risks involved in tapping markets.

Emerging Asia also needs to foster a credit culture to deepen its local debt markets. For now, the equity culture - combined with the comfortable liquidity position of banks and corporations - may be a hurdle for further expansion of local bond markets. However, in some countries (e.g., China and India), there are signs that economic growth is catalyzing a paradigmatic shift toward broader capital market development as the demand for corporate credit rises. Moreover, the fact that Asian corporations, which have historically been reliant on bank financing, were able to turn to local corporate bond markets when banks reduced lending during the global crisis, augurs well for market development (IMF (2010)). While it is difficult to define what constitutes a critical market size in terms of debt volume and number of issuers, the expansion in local debt markets in Asia could be rapid given the region's expected growth trajectory. 


\section{REFERENCES}

Arner, Douglas, Paul Lejot, and Lotte Schou-Zibell, 2008, "Securitization in East Asia," $A D B$ Working Paper Series on Regional Economic Integration, No. 12 (Manila: Asian Development Bank).

http://www.adb.org/documents/papers/regional-economic-integration/WP12-SecuritizationEast-Asia.pdf

APEC (Asia-Pacific Economic Cooperation), 2008, Report prepared for the Second PublicPrivate Sector Forum on Bond Market Development, Cusco, 9 July.

ASIFMA (Asia Securities Industry \& Financial Markets Association), 2010, Asian

Regulatory Review - Various Issues of Global Weekly Update.

http://www.sifma.org/blastemails/Global_Weekly_Update/Global_Weekly_Update-04-15-

$\underline{11 . h t m l}$

Asian Development Bank, 2010a, Asia Bond Monitor, March.

— 2010b, Asia Bond Monitor, Summer Edition.

- 2010c, Appendix III: Market Assessments, In ABMI Group of Experts Report:

Barriers to Cross-Border Investment and Settlement in ASEAN+3 Bond Markets, April.

Burger, John D., and Francis E. Warnock, 2006, "Local Currency Bond Markets," Staff

Papers, International Monetary Fund, Vol. 53, pp. 133-146.

http://www.imf.org/External/Pubs/FT/staffp/2006/03/burger.htm

Caballero, Ricardo J., 2006, “On the Macroeconomics of Asset Shortages," MIT Department of Economics Working Paper, No. 06-30 (Cambridge, MA: Massachusetts Institute of Technology).

Chami, Ralph, Connel Fullenkamp, and Sunil Sharma, 2010, "A Framework for Financial Market Development," Journal of Economic Policy Reform, Vol. 13, No.2, pp. 107-135.

Cheung, Stephen Y.L., and Hasung Jang, 2006, "Scoreboard on Corporate Governance in East Asia," The Center for International Governance Innovation Working Paper No. 13, December.

http://www.cigionline.org/publications/2006/12/scorecard-corporate-governance-east-asia

Committee on the Global Financial System (CGFS), 2007a, "Institutional Investors, Global Savings and Asset Allocation," CGFS Papers, No. 27 (February).

http://www.bis.org/publ/cgfs27.pdf

— 2007b, "Financial Stability and Local Currency Bond Markets," CGFS Papers, No. 28 (June). http://www.bis.org/publ/cgfs28.htm 
— , 2009, "Capital Flows and Emerging Market Economies," CGFS Papers, No. 33 (January). http://www.bis.org/publ/cgfs33.htm

Deutsche Bundesbank, International Monetary Fund, and The World Bank, 2009, Progress Report: Implementation of the G-8 Action Plan on Developing Local Bond Markets in Emerging Market Economies and Developing Countries. http://www.bundesbank.de/download/vfz/konferenzen/20080922 frankfurt/report.pdf

Eichengreen, Barry, and Pipat Luengnaruemitchai, 2004, "Why Doesn't Asia Have Bigger Bond Markets?" NBER Working Paper, No. 10576 (Cambridge, MA: National Bureau of Economic Research).

http://www.nber.org/papers/w10576

Eichengreen, Barry, Eduardo Borensztein, and Ugo Panizza, 2006, "A Tale of Two Markets: Bond Market Development in East Asia and Latin America," Hong Kong Institute for Monetary Research Occasional Paper, No. 3 (October).

www.hkimr.org/view attachment.asp?type $=22 \& i d=136$

Executives' Meeting of East Asia and Pacific Central Banks, 2005, The Asian Bond Fund 2 has Moved into Implementation Phase, May. http://aric.adb.org/initiativetable.php?iid $=67 \&$ ssid $=2 \&$ title $=$ Executives $\% 60 \% 20 \mathrm{Meeting} \% 20$ of $\% 20$ East $\% 20$ Asia $\% 20$ Pacific $\% 20$ Central $\% 20$ Banks $\% 20$ (EMEAP) $\% 20$ Asian $\% 20$ Bond $\% 2$ 0Fund $\% 20(\mathrm{ABF}) \% 20$ Initiative

Ghosh, Swati, 2006, East Asian Finance: The Road to Robust Markets, The World Bank (Washington D.C.). http://siteresources.worldbank.org/INTEAPREGTOPFINFINSECDEV/Resources/589748$\underline{1144293317827 / \text { full report.pdf }}$

Glaessner, Tom, 2008, Citi Indexes for EME Debt Markets: WGBI, Presentation for the Bretton Woods Committee and the Fletcher School Center for Emerging Market Enterprises Meeting on Strengthening Capital Markets in Emerging Market Countries, Washington, DC. 25 January.

Goldman Sachs, 2010, "EM Equity in Two Decades: A Changing Landscape," Global Economics Paper, No. 204, New York: Goldman Sachs (September).

Gyntelberg, Jacob 2007, "Developing Asia Pacific Non-government Fixed Income Markets," SBP Research Bulletin, Vol. 3, No. 1, pp. 7-26.

Gyntelberg, Jacob, Guonan Ma, and Eli M. Remolona, 2005, "Corporate Bond Markets in Asia," BIS Quarterly Review (December), pp. 83-93.

http://www.bis.org/publ/qtrpdf/r_qt0512.pdf

— , 2006, "Developing Corporate Bond Markets in Asia," BIS Papers, No. 26

(February). http://www.bis.org/publ/bppdf/bispap26.pdf 
International Finance Corporation, 2009, GEMLOC Investability Indicators - Phase 2 Extension, Second Quarterly Update (November).

http://indices.markit.com/download/products/guides/CRISIL_investibility_report.pdf

International Monetary Fund, 2010, Global Financial Stability Report, Washington, DC: IMF (October).

http://www.imf.org/External/Pubs/FT/GFSR/2010/02/index.htm

Jiang, Guorong, Nancy Tang, and Eve Law, 2002, "The Costs and Benefits of Developing Debt Markets: Hong Kong's Experience,” BIS Papers, No. 11 (June).

http://www.bis.org/publ/bppdf/bispap11h.pdf

J.P. Morgan Securities Inc., 2009, Emerging Markets Local Markets Overview, October.

__, 2009, Emerging Markets Outlook and Strategy, J.P. Morgan Emerging Markets

Research, January.

Kawai, Masahiro, 2007, "Bond Market Development in Emerging East Asia," Paper presented at the Federal Ministry of Finance and Deutsche Bundesbank High-Level Workshop on Developing Bond Markets in Emerging Market Economies, Frankfurt, Germany, 9-10 May.

http://www.bundesbank.de/download/vfz/konferenzen/20070509 10 frankfurt/paper kawai. pdf

Ma, Guonan, and Eli M. Remolona, 2005, “Opening Markets through a Regional Bond Fund: Lessons from ABF2,” BIS Quarterly Review (June), pp. 81-92.

http://www.bis.org/publ/qtrpdf/r_qt0506.pdf

Mieno, Fumiharu, and others, 2009, "Developing Bond Markets in Asia: Study Group on the Asian Financial System," Center for Monetary Cooperation in Asia, Bank of Japan. http://www.boj.or.jp/en/announcements/release_2009/data/cem0910.pdf

Mizen, Paul, and Serafeim Tsoukas, 2010, "What Effect has Bond Market Development in Emerging Asia had on the Issuance of Corporate Bonds?" Hong Kong Institute for Monetary Research Working Paper, No. 18 (June).

http://asianbondsonline.adb.org/publications/external/2010/bond_market development_effec t_corporate bonds.pdf

Monetary Authority of Singapore, 2010, 2009 Singapore Asset Management Industry Survey (July). http://www.mas.gov.sg/resource/eco_research/surveys/AssetMgmt09.pdf

OECD-World Bank Group-IMF Global Bond Market Forum, 2008, Secondary Market

Liquidity in Domestic Debt Markets, Washington, DC (April).

http://www.imf.org/external/np/seminars/eng/2008/bondmkt/pdf/key.pdf 
Parreñas, J.C., and Ken Waller, 2006, "Developing Bond Markets in APEC: Moving Forward Through Public-Private Sector Partnership,” ABA Journal XXI (2).

http://www.pecc.org/resources/doc view/584-moving-forward-through-public-privatesector-partnership-annex-b

Securities and Futures Commission, 2010, Fund Management Activities Survey 2009, Hong Kong, China, July.

http://www.sfc.hk/sfc/doc/EN/speeches/public/surveys/10/fmas_201007.pdf

Sheng, Andrew, 2010, “The Regulatory Reform of Global Financial Markets: An Asian Regulator's Perspective," Global Policy Vol. 1, No. 2, May.

Turner, Philip, 2007, "Local Currency Bond Markets in Emerging Market Economies: Notes on Trends, Measurement and Policy Challenges," Paper prepared for the G7 Workshop on Developing Bond Markets in Emerging Market Economies, Frankfurt, Germany, 9-10 May.

_ 2008, "The Investor Base and the Liquidity of EME Local Bond Markets: Leverage and Diversification," Paper presented at the 10th Annual OECD-World Bank-IMF Global Bond Market Forum, Washington, DC, 29-30 April.

— , 2009, "How have Local Currency Bond Markets in EMEs Weathered the Financial Crisis?" Presentation prepared for the 2nd International Workshop on Implementing G8 Action Plan, Frankfurt, Germany, 12-13 November. 